Article

\title{
Which Sustainability Dimensions Affect Credit Risk? Evidence from Corporate and Country-Level Measures
}

\author{
Lutfi Abdul Razak ${ }^{1, * \mathbb{D}}$, Mansor H. Ibrahim ${ }^{2}$ and Adam $\mathrm{Ng}^{3}$ \\ 1 UBD School of Business and Economics, Bandar Seri Begawan BE1410, Brunei Darussalam \\ INCEIF, Kuala Lumpur 59100, Malaysia; mansorhi@inceif.org \\ 3 WWF Malaysia, Selangor 46150, Malaysia; ngboonka@yahoo.com \\ * Correspondence: lutfi.razak@ubd.edu.bn
}

Received: 31 October 2020; Accepted: 2 December 2020; Published: 10 December 2020

check for updates

\begin{abstract}
Amid growing concern over sustainability issues, there is increasing demand to incorporate environmental and social issues into assessments of credit risk, the possibility of loss resulting from a borrower's failure to meet their financial obligations. In this paper, we sought to identify empirical evidence of a relationship between sustainability measures and credit risk. We contribute to this literature in three main ways: firstly, by using a measure that considers the financial materiality of sustainability issues across different industries; secondly, by using corporate default swap (CDS) spreads as a market-based measure of credit risk; and thirdly, by exploring the context-dependent nature of the relationship. Though the extent differs across industries, our results suggest risk-reducing effects across several corporate sustainability dimensions: climate change; natural resource use; human capital and corporate governance. Furthermore, we found that country sustainability plays a moderating role in the nexus between corporate sustainability and credit risk. Hence, a one- size-fits-all policy may not be suitable in developing the credit-relevant standardization of sustainability factors. Nevertheless, the robustness of corporate governance throughout our findings suggests that corporations should strengthen governance frameworks and procedures prior to embarking on environmental and social objectives to mitigate credit risk.
\end{abstract}

Keywords: corporate social performance; environmental; social and governance; corporate financial performance; corporate default swaps; credit risk; country sustainability

\section{Introduction}

Achieving the United Nations (UN) Sustainable Development Goals (SDGs) by 2030 is estimated to require at least USD 5-7 trillion dollars of annual investment across sectors and industries globally (UNCTAD 2014). Given the size, scale and level of sophistication of the global financial system, financing for sustainable development is available. Gross world product and global gross financial assets are estimated at over USD 80 trillion and USD 200 trillion, respectively (UN 2019). This need to finance sustainable development is connected to the concept of 'sustainable finance' which includes related, but distinct approaches, such as socially responsible investment (SRI) and environmental, social and governance (ESG) investing (UN Environment and World Bank 2017). While the SRI approach uses a negative screening list based on ethical or moral criteria to exclude investments in certain sectors such as tobacco and alcohol, ESG investing is an extension of the traditional type of investing wherein it seeks to maximize risk-adjusted returns, but uses broader ESG criteria as a screening tool.

As one of the main drivers of sustainable finance, the UN Principles for Responsible Investment (PRI) embarked on the 'ESG in Credit Ratings' initiative in 2016 to improve our understanding of how 
ESG factors affect credit risk analysis. Under this initiative, a dialogue between investors and credit rating agencies (CRAs) has uncovered several issues pertinent for future research. Firstly, PRI (2017) notes that while academic and market research establishes a 'clear link' between ESG factors and the credit risk of a borrower, too few studies are based on credit default swap (CDS) spreads. CDS spreads are increasingly popular among researchers in finance literature because they provide a market-based measure of credit risk (Fabozzi et al. 2003). Secondly, PRI (2017) has also highlighted the importance of distinguishing between ESG factors that are material from a business or investment perspective, and those that are material from a credit risk perspective. While most studies focus on aggregate measures of corporate social performance (CSP), significantly less attention is paid to identifying which dimensions of CSP affects credit risk. Finally, regional roundtables indicated that the appetite for ESG integration in credit analysis differs across jurisdictions and regions (PRI 2019). In particular, the global forums organized by PRI revealed regional differences on three levels: (i) the awareness and advancement of ESG consideration; (ii) the relative sensitivity to ESG factors by country; and (iii) the regulatory environment and attitudes towards it.

This paper seeks to fill the research gaps identified by the aforementioned issues in the following ways. Firstly, our study explicitly quantifies the credit risk effects associated with CSP dimensions using a new measure from Morgan Stanley Capital International (MSCI) ESG that considers the financial materiality of ESG issues across different industries. Prior to the work of Khan et al. (2016), most of the earlier studies relied on CSP measures which did not sufficiently account for the materiality of ESG issues across different industries. Secondly, unlike most other studies in the CSP-credit risk literature (Attig et al. 2013; Hoepner et al. 2016; Stellner et al. 2015), we used corporate default swap (CDS) spreads as a market-based measure of credit risk. If the ethical behavior of corporations is rewarded in credit markets, then the CSP measure should be negatively related to credit risk. As corporations are increasingly adopting value-relevant ESG information in order to maximize their shareholder value, this would enable us to explore the possibility of having a 'credit-relevant standardization on ESG-related issues' (PRI 2019). This can potentially help with the construction of an alternative scoring system for banks, one which includes social and environmental factors as well as financial elements (Gutierrez-Nieto et al. 2016; Zeidan et al. 2015). Finally, given the global variances in ESG adoption, we explore whether the relationship between CSP and credit risk is context-dependent, in terms of country sustainability.

Based on 2094 firm-year observations for 592 global non-financial firms between 2013 and 2016, we provide empirical evidence on which dimensions of corporate social performance (CSP) affect corporate creditworthiness. Using a dynamic panel model that accounts for the persistence of credit risk over time and controlling for a wide set of firm-specific and macroeconomic variables, several findings are notable. Firstly, we find evidence which suggests that CSP improvements lead to lower CDS spreads across the following dimensions: climate change; natural resource use; human capital and corporate governance. Secondly, we find that the benefits of CSP improvements to credit risk in these dimensions are greater for companies that are domiciled in countries with low sustainability scores. Finally, our findings suggest that country sustainability rather than corporate sustainability is a stronger determinant of corporate creditworthiness.

The rest of the paper is organized as follows. The next section briefly describes the related literature and develops the hypotheses. In Section 3, we describe our methodology, which comprises the sample selection, variable definitions and empirical approach. Subsequently, we present and discuss the results in Section 4. Finally, we provide concluding remarks in Section 5.

\section{Related Literature and Hypothesis Development}

There are two main opposing views regarding how corporate social performance (CSP) may affect creditworthiness: the risk mitigation view and the overinvestment view (Goss and Roberts 2011; Utz 2018). Based on stakeholder theory, the risk mitigation view posits that CSP tends to generate goodwill or moral capital for the firm. This refers to internal resources and intangibles such as better 
employee commitment, greater legitimacy among communities and regulators, improved level of trust among partners and suppliers, enhanced credibility and brand awareness, and more attractiveness for investors and lenders. This should result in lower cash flow volatility as it serves to protect or insure the company for when negative credit events occur, which improves their overall creditworthiness. Alternatively, the overinvestment view suggests that corporate social responsibility (CSR) initiatives constitute an agency cost or a wasteful diversion of resources which reduces firm value. This makes both shareholders and debtholders worse off, and in turn, reduces the companies' creditworthiness. Furthermore, firms with irresponsible business activities are more exposed to legal, regulatory, and reputational risks. This may entail penalties and fines and in turn, higher cash flow volatility and a diminished ability to repay debts.

Based on aggregate measures of CSP, the majority of previous empirical studies have indicated that better CSP is associated with higher credit ratings (Attig et al. 2013; Jiraporn et al. 2014; Sun and Cui 2014), lower loan spreads (Goss and Roberts 2011; Kim et al. 2014), lower bond spreads (Ge and Liu 2015; Huang et al. 2018; Oikonomou et al. 2014) and more recently, smaller CDS spreads (Drago et al. 2019; Kölbel et al. 2017). This supports the risk mitigation view. However, there is also some empirical support for the overinvestment view in terms of corporate bond spreads (Menz 2010), corporate bond ratings (Stellner et al. 2015), and bank loan spreads (Magnanelli and Izzo 2017). Most of these studies rely on aggregate measures of CSP. This includes the Kinder, Lydenberg and Domini (KLD) ratings, once recognized as the 'de facto standard' measure of CSP (Waddock 2003). Typically, the KLD dataset is operationalized by aggregating binary scores on strengths and concerns across dimensions to generate a composite score of CSP. This can be misleading, as firms perform good and bad deeds simultaneously across different dimensions (Perrault and Quinn 2018). Prior research has found empirical support for the construct validity (Sharfman 1996) and predictive validity (Chatterji et al. 2009) of the KLD ratings. However, Chatterji et al. (2009) also finds evidence to suggest that KLD does not make optimal use of the publicly available data. Furthermore, Capelle-Blancard and Petit (2015) found that the KLD dataset underweights environmental concerns and overweights controversial issues. Mattingly (2015) argues that the compositional procedures used to operationalize CSP using the KLD data in the extant literature may produce biased measures.

Partly motivated by concerns about aggregation, several empirical studies have also specifically explored the impact on credit risk of environmental issues (Capasso et al. 2020; Chava 2014; Jung et al. 2018; Nandy and Lodh 2012; Sharfman and Fernando 2008; Zerbib 2019), social issues (Chen et al. 2012; Kane et al. 2005; La Rosa et al. 2018; Verwijmeren and Derwall 2010) and governance issues (Alali et al. 2012; Ali et al. 2018; Ashbaugh-Skaife et al. 2006; Bhojraj and Sengupta 2003; Klock et al. 2005). All of these empirical studies support the risk mitigation view that better CSP is associated with a lower credit risk. Additionally, there are also a few studies that explore the risk effects of disaggregated KLD dimensions of US data. For example, Oikonomou et al. (2014) suggests that support for local communities, higher levels of marketed product safety and quality characteristics, and the avoidance of controversies regarding the firm's workforce, reduces the risk premia associated with corporate bonds and thus decreases the cost of corporate debt. Similarly, Bouslah et al. (2013) finds that the firm risk for S\&P500 members is positively affected by the employee, diversity, and corporate governance concerns. However, they find that for non-S\&P members, firm risk is positively affected by employee concerns and diversity strengths. Girerd-Potin et al. (2014) moved away from KLD dimensions and identified several independent and relevant socially responsible dimensions that reflect a firms' coherent posture towards social issues. In particular, they explored the link between stock returns and three socially responsible dimensions: business stakeholders (employees, customers, and suppliers); societal stakeholders (environment and society) and; financial stakeholders (stockholders and debt holders) and found that for each dimension, investors ask for an additional risk premium when accepting to hold non-socially responsible stocks.

Existing empirical studies on the relationship between CSP and corporate financial performance (CFP), which rely on composite CSP scores or disaggregated CSP dimensions, may be unreliable if 
it does not sufficiently account for the materiality of different ESG issues for companies in different industries. By merging KLD data with industry-specific guidance on materiality from the Sustainability Accounting Standards Board (SASB), Khan et al. (2016) find that firms with good ratings on immaterial sustainability issues do not significantly outperform firms with poor ratings on the same issues. Only firms with good ratings on material issues outperform firms with poor ratings on these issues. Therefore, it is possible that Khan et al. (2016) further argue that the relation between sustainability and financial performance would be significantly more robust if the financial materiality of sustainability issues are considered. The incorporation of materiality considerations into sustainability topics would arguably better capture the essence of CSP because it not does not sacrifice corporate profits at the expense of environmentally and socially oriented behavior.

The primary motivation of corporations in increasingly adopting ESG information is its relevance to business and investment performance (Amel-Zadeh and Serafeim 2018). To reflect growing demand, SRAs such as MSCI ESG have responded by incorporating the financial materiality of different ESG issues into sustainability metrics. MSCI ESG is the successor to the KLD database, which had been used extensively in academic research on CSP (Mattingly 2015; Perrault and Quinn 2018). However, there has been some debate as to what extent the KLD dataset is a valid indicator of what it purports to measure (Chatterji et al. 2009). Nevertheless, since its acquisition, MSCI ESG has substantially refined the scope and methodology originally employed by KLD. As Eccles and Stroehle (2018) explain, KLD had a values-driven definition of sustainability, with the vision 'to achieve greater accountability and, ultimately, a more just and sustainable world'. In contrast, MSCI ESG has adopted a value-driven definition of sustainability, by rating companies according to their exposure to industry-significant ESG risks and their ability to manage those risks relative to industry peers.

This paper seeks to contribute to the literature on sustainability and credit risk by exploring which dimensions of CSP affect credit risk. Using credit default swap (CDS) spreads as a market-based measure of credit risk, we expect better CSP to be associated with lower CDS spreads. This reasoning leads to the first hypothesis (H1) of our empirical study:

Hypothesis 1 (H1). There is a negative association between dimensions of corporate social performance (CSP) and corporate default swap (CDS) spreads.

Given the value-driven approach of MSCI ESG, which considers industry-specific environmental and social factors that are financially material, we expect the risk mitigation view to prevail. Specifically, we expect better CSP to be associated with lower credit default swap (CDS), a market-based measure of credit risk. However, this may not necessarily be the case across all dimensions, as materiality from a value creation perspective may not be the same as materiality from a credit risk perspective.

While some studies argue the CSP-CFP relationship is a virtuous circle in which one mutually reinforces the other (Orlitzky et al. 2003; Surroca et al. 2010), there is growing empirical support for the idea that the financial benefits of CSR activities are greater when there are institutional voids (El Ghoul et al. 2017; Su et al. 2016; Xiao et al. 2018). Using Tobin's q as a proxy for financial performance, Su et al. (2016) found that firms in emerging markets adopt CSR practices to positively signal to investors that their firms have superior capabilities of filling institutional voids. Similarly, El Ghoul et al. (2017) found that the value of corporate social responsibility (CSR) initiatives is greater in countries where an absence of market-supporting institutions increases transaction costs and limits access to resources. Furthermore, they also explore the channels through which CSR initiatives can compensate for institutional voids. In particular, they found that CSR is associated with improved access to financing in countries with weaker equity and credit markets, greater investment and lower default risk in countries with limited business freedom, and a longer trade credit period and higher future sales growth in countries with weaker legal institutions. More generally, Xiao et al. (2018) explains that country-level sustainability performance refers to 'the extent to which the tenets, principles, and practices of environmental integrity and social equity are institutionalized and embedded in 
a country'. They show that firms in countries with higher levels of sustainability performance do not benefit from CSP as much as their counterparts in countries with relatively lower levels of sustainability performance.

Companies operating in different jurisdictions may also be subject to different environmental regulations and social norms, as well governance requirements such as corporate responsibility disclosures. Several studies have highlighted the importance of country sustainability in the CSP-credit risk relationship (Hoepner et al. 2016; Stellner et al. 2015). Stellner et al. (2015) found some evidence that superior CSP results systematically reduced credit risk, and that the country's sustainability performance moderated the CSP-credit risk relationship. Hoepner et al. (2016) found that country sustainability, but not firm-level sustainability, influenced the interest rates charged to borrowing firms by banks.

Transaction cost theories suggest that specialized intermediaries, or institutions, emerge in order to resolve information and contracting problems, thus reducing transaction costs (Coase 1934; Williamson 1985). These transaction costs comprise the negotiating, monitoring and enforcement costs incurred for an exchange between parties to take place. In countries with institutional voids, CSR activities can reduce transaction costs and increase the access to capital, social, and reputational resources that are difficult to obtain. As a result, these activities provide a competitive advantage for firms operating in those countries. Therefore, if the relationship between CSP and corporate creditworthiness exists, it should be stronger in countries with lower sustainability performance. The second hypothesis (H2) that we test in this paper is stated as follows:

Hypothesis 2 (H2). The negative association between CSP dimensions and credit risk is stronger in countries with lower sustainability scores.

\section{Data and Methodology}

\subsection{Sample Selection}

Our initial MSCI ESG dataset comprises of 60,949 firm-year observations from companies with complete ESG data during the years 2013 and 2016. The sampling period was determined given that the ESG data prior to 2013 did not sufficiently account for the materiality of different ESG issues across industries (Nizam et al. 2019). In line with the literature (Goss and Roberts 2011; Stellner et al. 2015), financial companies are excluded from the sample since debt financing is treated differently compared to non-financial companies. With the exception of the MSCI ESG and country sustainability data, all continuous variables are winsorized at the $1 \%$ and $99 \%$ level, to mitigate the influence of outliers. This gives a final sample of 2094 firm-year observations for 592 global non-financial corporates during the period 2013-2016. As presented in Table 1, the firm-year observations are similarly distributed over time (Panel A), belong to different industries (Panel B) and are domiciled around the world (Panel C).

The sample is evenly distributed across years (panel A). In terms of sample distribution by industry (panel B), the highest number of firm-year observations was from the consumer discretionary (443) and industrials (421), while the least was from telecommunications services (82) and real estate (83). Finally, in terms of distribution by country (panel C), we found that more than three-quarters of the firm-year observations were domiciled in just four countries: United States; Japan; France; and the United Kingdom. This is generally consistent with the global distribution of listed non-financial corporations, which are predominantly domiciled in such developed economies. 
Table 1. Sample distribution.

\begin{tabular}{|c|c|c|c|c|c|}
\hline Panel A: By Year & & & $n$ & & \\
\hline 2013 & & & 523 & & \\
\hline 2014 & & & 518 & & \\
\hline 2015 & & & 523 & & \\
\hline 2016 & & & 530 & & \\
\hline Total & & & 2094 & & \\
\hline Panel B: By Industry & & & $n$ & & \\
\hline Energy & & & 147 & & \\
\hline Materials & & & 257 & & \\
\hline Industrials & & & 421 & & \\
\hline Consumer Discretionary & & & 443 & & \\
\hline Consumer Staples & & & 226 & & \\
\hline Health Care & & & 122 & & \\
\hline Information Technology & & & 157 & & \\
\hline Telecommunication Services & & & 82 & & \\
\hline Utilities & & & 156 & & \\
\hline Real Estate & & & 83 & & \\
\hline Total & & & 2094 & & \\
\hline Panel C: By Country & $n$ & Country & $n$ & Country & $n$ \\
\hline United States & 956 & Spain & 25 & Austria & 5 \\
\hline Japan & 411 & Finland & 23 & Belgium & 4 \\
\hline France & 130 & Malaysia & 20 & Israel & 4 \\
\hline United Kingdom & 124 & Italy & 18 & New Zealand & 4 \\
\hline Germany & 85 & Brazil & 16 & Norway & 4 \\
\hline Australia & 54 & China & 14 & Portugal & 4 \\
\hline South Korea & 43 & Denmark & 9 & Russia & 4 \\
\hline Hong Kong & 42 & Mexico & 9 & Thailand & 4 \\
\hline Sweden & 35 & Greece & 8 & Philippines & 1 \\
\hline Netherlands & 30 & Singapore & 8 & & \\
\hline Total & & & 2094 & & \\
\hline
\end{tabular}

Notes: sample distributions are given by year (panel A), by industry (panel B) and by country (panel C).

\subsection{Variables}

\subsubsection{Corporate Default Swap (CDS) Spreads}

We used credit default swap (CDS) spreads as a market-based proxy of credit risk as it reflects the compensation that market participants are willing to pay for bearing that risk (Das et al. 2009). This makes it a better measure of credit risk relative to bonds or loan spreads (Longstaff et al. 2005), which marks our first contribution to the literature. In line with previous studies (Kölbel et al. 2017; Tolikas and Topaloglou 2017), we obtained CDS spreads per individual from Thomson Reuters, which provides composite prices of CDS by taking daily CDS quotes from over 30 global contributors. The Reuters CDS spread is presented as the CDS premium mid, or the mid-rate spread between the entity and the relevant benchmark curve expressed in basis points. In order to eliminate the influence of outliers or doubtful data, the Reuters CDS employs a rigorous screening procedure prior to computing a daily composite spread. We extracted a time series of 5-year annual CDS spreads as it is the most liquid contract and hence the most accurately priced (Longstaff et al. 2005). Finally, we used a log-transformation of the CDS spreads given the variable has a right-skewed distribution.

\subsubsection{Corporate Social Performance (CSP) Dimensions}

We used CSP dimensions provided by MSCI ESG which makes an explicit assessment of the ESG issues that have a material impact on the company. MSCI ESG aims to answer the following two questions: (i) of the negative externalities that companies in an industry generate, which issues 
may turn into unanticipated costs for companies in the medium to long term? (ii) Conversely, which ESG issues affecting an industry may turn into opportunities for companies in the medium to long term? MSCI ESG identifies six to ten key ESG issues where companies in that industry currently generate large environmental or social externalities and where some companies may be forced to internalize unanticipated costs associated with those externalities in the future. A risk (opportunity) is material to an industry when it is likely that companies in a given industry will accrue costs (benefits) in connection with it. Based on MSCI ESG's materiality mapping framework, these key issues are scored and weighted to produce the following dimensions: climate change, natural resource use, waste management, environmental opportunities, human capital, product liability, social opportunities, stakeholder opposition, corporate governance and business ethics. Testing the importance of these disaggregated dimensions relative to credit risk marks our second contribution to the literature.

\subsubsection{Country Sustainability}

With the Bloomberg ESG country tool, which assesses in a manner similar to Stellner et al. (2015), we used country sustainability variables provided by the environmental, social, and strategic governance risk faced by different countries. The tool identifies 76 indicators of the long-term sustainability prospects of a country and calculates the country's percentile rank for each individual indicator. The Bloomberg tool provides an overall country sustainability score as well as component scores. While Stellner et al. (2015) uses a dummy variable to categorize high and low sustainability countries, we use the overall score and environmental, social and strategic governance risk scores to represent country-level sustainability, denoted, respectively, as C_ESG, C_ENV, C_SOC, and C_GOV. Using these measures to assess the context-dependent nature of the relationship between corporate sustainability and credit risk marks our third contribution to the literature.

\subsubsection{Control Variables}

The large empirical literature on the determinants of CDS spreads consists of firm-level and macroeconomic variables (Lee et al. 2016; Tang and Yan 2010). These variables are obtained from Thomson Reuters Datastream, unless stated otherwise. In this paper, we include the following firm-level control variables: distance-to-default; firm size; leverage; profitability; liquidity; and stock volatility. Distance-to-default (DTD) is a measure of default risk, based on the transformed-data maximum likelihood method (Duan 1994; Duan and Laere 2012). This measure is obtained from the Risk Management Institute at the National University of Singapore. Firm size is measured by the natural logarithm of market capitalization (Size). While larger firms have greater capacity to repay their debts (Lee et al. 2016; Oikonomou et al. 2014), they also tend to attract more attention from stakeholders in response to ESG issues (Jiraporn et al. 2014). Leverage is measured by the ratio of total debt to total assets (TD/TA) and the ratio of short-term to long-term debt (ST/LT). Highly leveraged companies face a higher default risk and have higher credit spreads (Attig et al. 2013; Magnanelli and Izzo 2017). Profitability is measured by the market-to-book ratio (MV/BV) and the earnings before interest and tax margin (Margin). More profitable firms have greater capacity to repay debts and ability to invest in socially responsible activities (Hoepner et al. 2016; Lee et al. 2016). Liquidity is measured by the ratio of cash from operations to total assets (CASH/TA) and the ratio of current assets to current liabilities (CA/CL). More liquid companies are better able to repay their debts on time and tend to have a lower credit risk (Brogaard et al. 2017; Corò et al. 2013; Das and Hanouna 2009). Equity volatility is measured as the annualized standard deviation of continuously compounded daily stock returns (STKVOL). Higher equity volatility is associated with larger credit spreads (Campbell and Taksler 2003; Lee and Hyun 2019).

We also included the following macroeconomic control variables: GDP per capita, GDP growth, market volatility and sovereign risk. The natural logarithm of GDP per capita is used to control for the size of the economy in which the corporation is domiciled. However, its effect on corporate credit risk is unclear (La Rosa et al. 2018; Lee et al. 2016). GDP growth controls for the effects of the business 
cycle, and economic growth should be associated with better business prospects and lower default probabilities (Tang and Yan 2010). Data on GDP per capita (YPC) and GDP growth $(\Delta \mathrm{Y})$ were obtained from the World Bank. Market volatility (MKTVOL) is measured as the standard deviation of weekly log returns each year (Lee et al. 2016), which should be positively correlated with credit spreads (Collin-Dufresne et al. 2001; Schaefer and Strebulaev 2008). Sovereign risk (sovereign) is measured as the natural logarithm of the sovereign 5-year CDS spread (Lee et al. 2016), and should be positively related to corporate credit spreads (Bedendo and Colla 2015; Klein and Stellner 2014).

\subsection{Empirical Approach}

In order to test our first hypothesis $\mathrm{H} 1$, we used the following dynamic panel model to examine the relationship between CSP dimensions and credit risk:

$$
y_{i, j, t}=\theta y_{i, j, t}+\beta_{1} \operatorname{CSP}_{i, j, t-1}+\gamma F_{i, j, t-1}+\delta M_{j, t-1}+\mu_{i}+\varepsilon_{i, t}
$$

where $y_{i, j, t}$ is the corporate default swap (CDS) spreads and CSP $P_{i, j, t}$ is the dimension of CSP, whereas $F_{i, j, t}$ and $M_{j, t}$ are the vectors of firm-specific and macroeconomic control variables, respectively. The subscript $i$ refers to firm, $j$ to country and $t$ to year. The inclusion of the lagged dependent variable is used to capture the persistence of credit risk over time. We lag the explanatory variables by one period to address the potential endogeneity concerns.

In order to test our second hypothesis (H2), we augmented Equation (1) as follows:

$$
y_{i, j, t}=\theta y_{i, j, t}+\beta_{1} \operatorname{CSP} P_{i, j, t-1}+\beta_{2} Z_{j, t-1}+\beta_{3}\left(\operatorname{CSP}_{i, j, t-1} \times Z_{j, t-1}\right)+\gamma F_{i, j, t-1}+\delta M_{j, t-1}+\mu_{i}+\varepsilon_{i, t}
$$

where $Z_{j, t}$ is the measure of country sustainability for country $j$ where the company is domiciled at year $t$. The key parameters in the above model are $\beta_{1}$ and $\beta_{3}$. Due to the presence of the interaction term, they cannot be interpreted independently from each other given that the impact of CSP on credit risk is now made dependent on the country level of sustainability. Following the recommendation by Brambor et al. (2006), we substantively computed the marginal effects of CSP on CDS spreads, as well as their corresponding standard errors. These are computed at various levels of country sustainability score, ranging from its minimum to its maximum.

To estimate the above models, we employed the two-step System Generalized Method of Moments (GMM) estimator developed by Arellano and Bover (1995) and Blundell and Bond (1998). The GMM procedure has been widely adopted in the literature to address the endogeneity issue arising from the inclusion of the lagged dependent variable and omitted variable bias. We use Windmeijer's (2005) corrected standard errors to reduce the downward bias of the two-step procedure resulting from small T, large N panels. Following Roodman (2009), we apply orthogonal deviations to filter out firm-specific effects and include time dummies. These would ensure that the assumption of no correlation across individuals in the idiosyncratic error term is more likely to hold. To verify the consistency of the estimates, we tested the validity of the instruments using the Hansen test and subject the error terms to Arellano-Bond autocorrelation (AR) tests. The latter requires the absence of error autocorrelation of order 2.

\section{Results}

\subsection{Preliminary Analysis}

Table 2 shows the descriptive statistics for the variables under investigation including the corporate and country sustainability variables, while Table 3 shows the correlation coefficients. Given the disparity in the number of observations for pillar-level corporate sustainability variables, we do not include them in Table 3. With the exception of the YPC and sovereign, none of the variables have a correlation coefficient greater than 0.7 , and thus multicollinearity should not be a major issue. 
Table 2. Descriptive statistics.

\begin{tabular}{|c|c|c|c|c|c|c|}
\hline $\begin{array}{c}\text { Firm-Level } \\
\text { Variables }\end{array}$ & $\mathbf{N}$ & Mean & SD & Minimum & Median & Maximum \\
\hline$C D S$ & 2094 & 4.43 & 0.79 & 3.02 & 4.32 & 6.80 \\
\hline DTD & 2094 & 6.16 & 2.96 & 0.40 & 5.82 & 14.50 \\
\hline Size & 2094 & 9.57 & 1.22 & 6.74 & 9.54 & 12.31 \\
\hline$T D / T A$ & 2094 & 0.30 & 0.14 & 0.03 & 0.28 & 0.70 \\
\hline$S T / L T$ & 2094 & 0.07 & 0.12 & 0.00 & 0.00 & 0.61 \\
\hline$M V / B V$ & 2094 & 3.40 & 6.26 & -12.18 & 2.06 & 48.46 \\
\hline Margin & 2094 & 12.44 & 9.96 & -10.89 & 10.53 & 54.14 \\
\hline$C A / C L$ & 2094 & 1.45 & 0.74 & 0.35 & 1.29 & 4.71 \\
\hline $\mathrm{CASH} / \mathrm{TA}$ & 2094 & 0.09 & 0.05 & -0.04 & 0.08 & 0.25 \\
\hline STKVOL & 2094 & 0.28 & 0.10 & 0.13 & 0.26 & 0.65 \\
\hline Climate & 2050 & 7.15 & 2.54 & 0.00 & 7.65 & 10.00 \\
\hline Resource & 1954 & 5.46 & 2.51 & 0.00 & 5.20 & 10.00 \\
\hline WasteMgt & 1937 & 5.93 & 2.45 & 0.00 & 5.98 & 10.00 \\
\hline EnvOpps & 926 & 5.40 & 1.66 & 0.08 & 5.49 & 9.77 \\
\hline HumanCap & 2075 & 4.69 & 1.98 & 0.00 & 4.73 & 10.00 \\
\hline ProdSafe & 1127 & 4.00 & 2.18 & 0.00 & 3.85 & 10.00 \\
\hline SocialOpps & 316 & 5.35 & 1.66 & 0.70 & 5.40 & 9.50 \\
\hline Stakehldr & 33 & 5.67 & 2.16 & 0.80 & 5.80 & 9.60 \\
\hline CorpGov & 2091 & 6.24 & 2.41 & 0.00 & 6.25 & 10.00 \\
\hline BusEthics & 753 & 4.43 & 1.79 & 0.00 & 4.38 & 9.90 \\
\hline \multicolumn{7}{|c|}{ Country-Level Variables } \\
\hline$Y P C$ & 2094 & 10.71 & 0.31 & 9.15 & 10.82 & 10.94 \\
\hline$\Delta Y$ & 2094 & 1.90 & 0.97 & -1.13 & 1.74 & 5.11 \\
\hline MKTVOL & 2094 & 0.02 & 0.01 & 0.01 & 0.02 & 0.05 \\
\hline Sovereign & 2094 & 3.22 & 0.58 & 2.16 & 3.09 & 5.37 \\
\hline C_ESG & 2094 & 55.41 & 2.78 & 40.94 & 55.84 & 63.63 \\
\hline C_ENV & 2094 & 43.78 & 8.63 & 15.84 & 41.00 & 58.14 \\
\hline C_SOC & 2094 & 52.37 & 3.77 & 38.09 & 50.82 & 65.05 \\
\hline C_GOV & 2094 & 73.94 & 5.94 & 35.25 & 74.34 & 86.79 \\
\hline
\end{tabular}

Notes: $C D S$ = natural logarithm of corporate default swap (CDS) spreads; DTD = distance-to-default; Size = natural logarithm of market capitalization in USD millions; $T D / T A=$ debt-to-total assets ratio; $S T / L T=$ ratio of total short-term debt to total long-term debt; $M V / B V=$ market-to-book ratio; Margin = EBIT margin; $C A / C L=$ ratio of current assets to liabilities, $S T K V O L=$ annualized standard deviation of daily stock returns, $C A S H / T A=$ ratio of cash from operations to total assets; $Y P C=$ natural logarithm of GDP per capita; $\triangle Y=$ GDP growth; $M K T V O L=$ annual standard deviation of log weekly returns; Sovereign = natural logarithm of sovereign 5-year CDS spread; climate = climate change score; Resource = natural resource use score; WasteMgt = waste management score; EnvOpps = environmental opportunities score; HumanCap = human capital score; ProdSafe = product safety score; SocOpps = social opportunities score; Stakehldr = stakeholder opposition score; CorpGov = corporate governance score; BusEthics = business ethics score; C_ESG = country sustainability; C_ENV = country environmental risk; C_SOC $=$ country social risk; and C_GOV = country strategic governance risk.

\subsection{The Effects of Corporate Social Performance (CSP) Dimensions on Credit Risk}

To test our first hypothesis, Table 4 presents the estimation results for the effects of CSP dimensions on CDS spreads under System GMM with Windmeijer (2005) corrected standard errors. We explored the effect on CDS spreads of the following environmental dimensions: climate change (model 1), natural resource use (model 2), pollution and waste (model 3), environmental opportunities (model 4); social dimensions: human capital (model 5), product liability (model 6), social opportunities (model 7); governance dimensions: corporate governance (model 8) and business ethics (model 9). Throughout all the estimations, the results show that the lagged dependent variable is highly significant at the $1 \%$ level with coefficients greater than 0.6. Furthermore, diagnostic tests suggest the absence of the autocorrelation of order two, which implies that the System GMM is correctly specified. Additionally, the number of instruments is lower than the number of firms, so there should be no issue with regards to instrument proliferation. 
Table 3. Correlation coefficients.

\begin{tabular}{|c|c|c|c|c|c|c|c|c|c|c|c|c|c|c|c|c|c|c|c|}
\hline & & (1) & $(2)$ & (3) & (4) & (5) & (6) & (7) & $(8)$ & (9) & (10) & (11) & (12) & (13) & (14) & (15) & (16) & (17) & (18) \\
\hline (1) & CDS & 1 & & & & & & & & & & & & & & & & & \\
\hline (2) & DTD & -0.429 & 1 & & & & & & & & & & & & & & & & \\
\hline (3) & SIZE & -0.491 & 0.479 & 1 & & & & & & & & & & & & & & & \\
\hline (4) & $T D / T A$ & 0.237 & -0.125 & -0.144 & 1 & & & & & & & & & & & & & & \\
\hline (5) & $S T / L T$ & -0.155 & -0.038 & -0.018 & -0.129 & 1 & & & & & & & & & & & & & \\
\hline (6) & $M V / B V$ & -0.093 & 0.217 & 0.162 & 0.104 & -0.061 & 1 & & & & & & & & & & & & \\
\hline (7) & Margin & -0.116 & 0.382 & 0.301 & 0.079 & -0.146 & 0.118 & 1 & & & & & & & & & & & \\
\hline (8) & $C A / C L$ & 0.008 & 0.110 & -0.081 & -0.247 & 0.006 & -0.038 & 0.051 & 1 & & & & & & & & & & \\
\hline (9) & CASH/TA & -0.203 & 0.416 & 0.296 & -0.021 & -0.103 & 0.289 & 0.288 & 0.060 & 1 & & & & & & & & & \\
\hline (10) & STKVOL & 0.433 & -0.681 & -0.459 & 0.107 & 0.103 & -0.140 & -0.355 & 0.083 & -0.285 & 1 & & & & & & & & \\
\hline (11) & $Y P C$ & -0.215 & 0.110 & 0.046 & -0.007 & -0.019 & 0.088 & -0.089 & -0.040 & 0.059 & -0.078 & 1 & & & & & & & \\
\hline (12) & $\Delta Y$ & 0.155 & 0.195 & 0.046 & 0.020 & -0.147 & 0.119 & 0.147 & 0.042 & 0.148 & -0.131 & -0.166 & 1 & & & & & & \\
\hline (13) & STKVOL & -0.126 & -0.184 & -0.110 & 0.001 & 0.144 & -0.100 & -0.135 & 0.027 & -0.150 & 0.215 & -0.024 & -0.440 & 1 & & & & & \\
\hline (14) & Sovereign & 0.158 & -0.152 & -0.074 & -0.005 & 0.052 & -0.105 & 0.090 & 0.035 & -0.069 & 0.056 & -0.700 & -0.102 & 0.353 & 1 & & & & \\
\hline (15) & C_ESG & -0.262 & 0.012 & -0.032 & 0.019 & 0.094 & 0.025 & -0.190 & 0.024 & 0.053 & 0.015 & 0.566 & -0.014 & 0.147 & -0.503 & 1 & & & \\
\hline (16) & $C_{-} E N V$ & 0.057 & 0.272 & 0.110 & 0.179 & -0.217 & 0.169 & 0.038 & 0.061 & 0.270 & -0.096 & 0.333 & 0.178 & -0.132 & -0.346 & 0.368 & 1 & & \\
\hline (17) & C_SOC & -0.194 & -0.240 & -0.018 & -0.039 & 0.138 & -0.067 & -0.200 & -0.091 & -0.047 & 0.103 & -0.014 & -0.136 & 0.030 & -0.152 & 0.525 & -0.205 & 1 & \\
\hline (18) & C_GOV & -0.221 & 0.052 & -0.022 & -0.085 & 0.053 & 0.053 & -0.054 & -0.036 & 0.014 & -0.111 & 0.671 & -0.013 & -0.098 & -0.527 & 0.534 & -0.130 & 0.234 & 1 \\
\hline
\end{tabular}

Note: please refer to Tables 1 and 2 . 
Table 4. System GMM estimation results for the effects of corporate social performance (CSP) dimensions on corporate default swap (CDS) spreads.

\begin{tabular}{|c|c|c|c|c|c|c|c|c|c|}
\hline & (1) & $(2)$ & (3) & (4) & (5) & (6) & (7) & (8) & (9) \\
\hline$C D S_{i t-1}$ & $\begin{array}{c}0.7343^{* * *} \\
(0.054)\end{array}$ & $\begin{array}{c}0.7378^{* * *} \\
(0.058)\end{array}$ & $\begin{array}{c}0.7545^{* * *} \\
(0.054)\end{array}$ & $\begin{array}{c}0.6137 * * * \\
(0.066)\end{array}$ & $\begin{array}{c}0.7503 * * * \\
(0.053)\end{array}$ & $\begin{array}{c}0.6858 * * * \\
(0.063)\end{array}$ & $\begin{array}{c}0.8746 * * * \\
(0.071)\end{array}$ & $\begin{array}{c}0.7414^{* * *} \\
(0.053)\end{array}$ & $\begin{array}{c}0.7038 * * * \\
(0.066)\end{array}$ \\
\hline Dimension & $\begin{array}{c}-0.0099^{* * * *} \\
(0.003)\end{array}$ & $\begin{array}{c}-0.0095^{* * *} \\
(0.004)\end{array}$ & $\begin{array}{l}-0.0007 \\
(0.003)\end{array}$ & $\begin{array}{c}-0.0080 \\
(0.009)\end{array}$ & $\begin{array}{c}-0.0140^{* * * *} \\
(0.004)\end{array}$ & $\begin{array}{c}-0.0020 \\
(0.005)\end{array}$ & $\begin{array}{c}-0.0142 \\
(0.012)\end{array}$ & $\begin{array}{c}-0.0102 * * * \\
(0.004)\end{array}$ & $\begin{array}{l}-0.0111 \\
(0.007)\end{array}$ \\
\hline DTD & $\begin{array}{c}-0.0063 \\
(0.004)\end{array}$ & $\begin{array}{l}-0.0074 \\
(0.004)\end{array}$ & $\begin{array}{c}-0.0058 \\
(0.004)\end{array}$ & $\begin{array}{l}-0.0067 \\
(0.009)\end{array}$ & $\begin{array}{c}-0.0064 \\
(0.004)\end{array}$ & $\begin{array}{l}-0.0007 \\
(0.006)\end{array}$ & $\begin{array}{l}0.0054 \\
(0.007)\end{array}$ & $\begin{array}{c}-0.0070 \\
(0.004)\end{array}$ & $\begin{array}{c}-0.0065 \\
(0.007)\end{array}$ \\
\hline SIZE & $\begin{array}{c}-0.0560^{* * *} \\
(0.012)\end{array}$ & $\begin{array}{c}-0.0549^{* * *} \\
(0.013)\end{array}$ & $\begin{array}{c}-0.0590^{* * *} \\
(0.012)\end{array}$ & $\begin{array}{c}-0.0932 * * * \\
(0.018)\end{array}$ & $\begin{array}{c}-0.0595^{* * *} \\
(0.012)\end{array}$ & $\begin{array}{c}-0.0802^{* * *} \\
(0.018)\end{array}$ & $\begin{array}{c}-0.0238 \\
(0.022)\end{array}$ & $\begin{array}{c}-0.0601 * * * \\
(0.012)\end{array}$ & $\begin{array}{c}-0.0587^{* * *} \\
(0.016)\end{array}$ \\
\hline$T D / T A$ & $\begin{array}{c}0.2062 * * * \\
(0.079)\end{array}$ & $\begin{array}{c}0.1759 \text { ** } \\
(0.080)\end{array}$ & $\begin{array}{c}0.2023^{* * *} \\
(0.077)\end{array}$ & $\begin{array}{c}0.2775 \text { ** } \\
(0.130)\end{array}$ & $\begin{array}{c}0.1975 * * * \\
(0.075)\end{array}$ & $\begin{array}{c}0.3009 * * * \\
(0.113)\end{array}$ & $\begin{array}{l}0.2090 \\
(0.148)\end{array}$ & $\begin{array}{c}0.1940 \text { ** } \\
(0.077)\end{array}$ & $\begin{array}{c}0.1945^{*} \\
(0.113)\end{array}$ \\
\hline ST/LT & $\begin{array}{c}-0.1336 \\
(0.085)\end{array}$ & $\begin{array}{c}-0.1399 \\
(0.085)\end{array}$ & $\begin{array}{c}-0.1242 \\
(0.083)\end{array}$ & $\begin{array}{c}-0.0449 \\
(0.124)\end{array}$ & $\begin{array}{c}-0.0956 \\
(0.079)\end{array}$ & $\begin{array}{c}-0.2166^{*} \\
(0.125)\end{array}$ & $\begin{array}{c}-0.1564 \\
(0.187)\end{array}$ & $\begin{array}{c}-0.1297 \\
(0.084)\end{array}$ & $\begin{array}{c}-0.1741 \\
(0.128)\end{array}$ \\
\hline$M V / B V$ & $\begin{array}{c}-0.0014 \\
(0.001)\end{array}$ & $\begin{array}{l}-0.0016 \\
(0.001)\end{array}$ & $\begin{array}{c}-0.0016 \\
(0.001)\end{array}$ & $\begin{array}{l}0.0028 \\
(0.002)\end{array}$ & $\begin{array}{c}-0.0016 \\
(0.001)\end{array}$ & $\begin{array}{c}-0.0012 \\
(0.001)\end{array}$ & $\begin{array}{c}-0.0007 \\
(0.002)\end{array}$ & $\begin{array}{c}-0.0016^{*} \\
(0.001)\end{array}$ & $\begin{array}{c}-0.0039 * * \\
(0.002)\end{array}$ \\
\hline Margin & $\begin{array}{l}0.0019 \text { *** } \\
(0.001)\end{array}$ & $\begin{array}{l}0.0018^{* *} \\
(0.001)\end{array}$ & $\begin{array}{l}0.0016 \text { ** } \\
(0.001)\end{array}$ & $\begin{array}{l}0.0035^{* * *} \\
(0.002)\end{array}$ & $\begin{array}{l}0.0016 \text { ** } \\
(0.001)\end{array}$ & $\begin{array}{l}-0.0007 \\
(0.001)\end{array}$ & $\begin{array}{l}0.0005 \\
(0.003)\end{array}$ & $\begin{array}{c}0.0018^{* *} \\
(0.001)\end{array}$ & $\begin{array}{c}0.0048^{* * *} \\
(0.001)\end{array}$ \\
\hline$C A / C L$ & $\begin{array}{l}0.0199 \text { *** } \\
(0.010)\end{array}$ & $\begin{array}{l}0.0113 \\
(0.010)\end{array}$ & $\begin{array}{l}0.0200 \text { ** } \\
(0.010)\end{array}$ & $\begin{array}{l}0.0310^{* *} \\
(0.015)\end{array}$ & $\begin{array}{l}0.0197 * * \\
(0.009)\end{array}$ & $\begin{array}{c}-0.0001 \\
(0.015)\end{array}$ & $\begin{array}{c}-0.0101 \\
(0.028)\end{array}$ & $\begin{array}{l}0.0157 \\
(0.010)\end{array}$ & $\begin{array}{l}0.0004 \\
(0.018)\end{array}$ \\
\hline $\mathrm{CASH} / \mathrm{TA}$ & $\begin{array}{l}0.2647 \\
(0.188)\end{array}$ & $\begin{array}{c}0.4228^{* *} \\
(0.187)\end{array}$ & $\begin{array}{c}0.4476^{* *} \\
(0.181)\end{array}$ & $\begin{array}{c}-0.1913 \\
(0.303)\end{array}$ & $\begin{array}{c}0.3956^{* *} \\
(0.180)\end{array}$ & $\begin{array}{l}-0.1390 \\
(0.273)\end{array}$ & $\begin{array}{l}-0.4536 \\
(0.381)\end{array}$ & $\begin{array}{l}0.3429^{*} \\
(0.182)\end{array}$ & $\begin{array}{l}0.2986 \\
(0.297)\end{array}$ \\
\hline STKVOL & $\begin{array}{c}0.5275^{* * *} \\
(0.179)\end{array}$ & $\begin{array}{c}0.5324^{* * *} \\
(0.192)\end{array}$ & $\begin{array}{c}0.4804^{* * *} \\
(0.173)\end{array}$ & $\begin{array}{c}0.5752^{* *} \\
(0.284)\end{array}$ & $\begin{array}{c}0.4853^{* * *} \\
(0.175)\end{array}$ & $\begin{array}{c}0.7309^{* * *} \\
(0.218)\end{array}$ & $\begin{array}{l}0.4527 \\
(0.404)\end{array}$ & $\begin{array}{c}0.5156^{* * *} \\
(0.178)\end{array}$ & $\begin{array}{c}0.8847^{* * *} \\
(0.249)\end{array}$ \\
\hline$Y P C$ & $\begin{array}{c}-0.0562 * \\
(0.032)\end{array}$ & $\begin{array}{c}-0.0504 \\
(0.037)\end{array}$ & $\begin{array}{c}-0.0659 * \\
(0.039)\end{array}$ & $\begin{array}{c}-0.1937^{* * *} \\
(0.070)\end{array}$ & $\begin{array}{c}-0.0351 \\
(0.029)\end{array}$ & $\begin{array}{l}-0.0108 \\
(0.060)\end{array}$ & $\begin{array}{l}0.0364 \\
(0.078)\end{array}$ & $\begin{array}{c}-0.0512 * \\
(0.030)\end{array}$ & $\begin{array}{l}-0.0374 \\
(0.046)\end{array}$ \\
\hline$\Delta Y$ & $\begin{array}{c}0.0226^{* * *} \\
(0.008)\end{array}$ & $\begin{array}{c}0.0180^{* *} \\
(0.008)\end{array}$ & $\begin{array}{c}0.0234^{* * *} \\
(0.008)\end{array}$ & $\begin{array}{c}0.0449^{* * * *} \\
(0.014)\end{array}$ & $\begin{array}{c}0.0232^{* * *} \\
(0.008)\end{array}$ & $\begin{array}{c}0.0269^{* *} \\
(0.013)\end{array}$ & $\begin{array}{c}-0.0198 \\
(0.022)\end{array}$ & $\begin{array}{c}0.0277^{* * *} \\
(0.008)\end{array}$ & $\begin{array}{c}0.0351^{* * * *} \\
(0.012)\end{array}$ \\
\hline MKTVOL & $\begin{array}{c}-10.8673^{* * *} \\
(1.821)\end{array}$ & $\begin{array}{c}-11.1249^{* * *} \\
(2.093)\end{array}$ & $\begin{array}{c}-11.0446^{* * *} \\
(1.953)\end{array}$ & $\begin{array}{c}-12.3092^{* * *} \\
(2.331)\end{array}$ & $\begin{array}{c}-10.4142^{* * *} \\
(1.796)\end{array}$ & $\begin{array}{c}-13.4127 * * * \\
(2.045)\end{array}$ & $\begin{array}{c}-7.8630 * * \\
(3.380)\end{array}$ & $\begin{array}{c}-10.4184^{* * *} \\
(1.803)\end{array}$ & $\begin{array}{c}-8.5336^{* * *} \\
(1.919)\end{array}$ \\
\hline Sovereign & $\begin{array}{l}0.0231 \\
(0.020)\end{array}$ & $\begin{array}{l}0.0205 \\
(0.021)\end{array}$ & $\begin{array}{l}0.0190 \\
(0.020)\end{array}$ & $\begin{array}{l}0.0308 \\
(0.035)\end{array}$ & $\begin{array}{l}0.0232 \\
(0.019)\end{array}$ & $\begin{array}{c}0.0771^{* * *} \\
(0.028)\end{array}$ & $\begin{array}{c}0.0797^{* *} \\
(0.040)\end{array}$ & $\begin{array}{l}0.0219 \\
(0.019)\end{array}$ & $\begin{array}{l}0.0102 \\
(0.025)\end{array}$ \\
\hline $\begin{array}{l}\text { Year } \\
\text { Constant }\end{array}$ & $\begin{array}{c}\text { Yes } \\
2.2429^{* * *} \\
(0.546)\end{array}$ & $\begin{array}{c}\text { Yes } \\
2.1687^{* * *} \\
(0.601)\end{array}$ & $\begin{array}{c}\text { Yes } \\
2.2376^{* * *} \\
(0.625)\end{array}$ & $\begin{array}{c}\text { Yes } \\
4.4784^{* * *} \\
(0.987)\end{array}$ & $\begin{array}{c}\text { Yes } \\
1.9650^{* * *} \\
(0.506)\end{array}$ & $\begin{array}{c}\text { Yes } \\
2.0377^{* *} \\
(0.920)\end{array}$ & $\begin{array}{c}\text { Yes } \\
0.2137 \\
(1.042)\end{array}$ & $\begin{array}{c}\text { Yes } \\
2.1963^{* * *} \\
(0.535)\end{array}$ & $\begin{array}{c}\text { Yes } \\
2.0080^{* * *} \\
(0.759)\end{array}$ \\
\hline \# of Observations & 2050 & 1954 & 1937 & 926 & 2075 & 1127 & 316 & 2091 & 753 \\
\hline \# of Firms & 582 & 557 & 548 & 266 & 589 & 349 & 98 & 591 & 223 \\
\hline \# of Instruments & 27 & 27 & 27 & 27 & 27 & 27 & 27 & 27 & 27 \\
\hline Hansen Test & 0.1158 & 0.3209 & 0.3192 & 0.0835 & 0.2971 & 0.4585 & 0.4712 & 0.3043 & 0.0878 \\
\hline $\mathrm{AR}(1)$ & 0.0000 & 0.0000 & 0.0000 & 0.0000 & 0.0000 & 0.0000 & 0.0000 & 0.0000 & 0.0000 \\
\hline $\mathrm{AR}(2)$ & 0.4981 & 0.4067 & 0.8176 & 0.2521 & 0.2926 & 0.5421 & 0.6142 & 0.3460 & 0.4690 \\
\hline
\end{tabular}

(4) environmental opportunities; (5) human capital; (6) product safety; (7) social opportunities; (8) corporate governance; and (9) business ethics. \# refers to the number. AR (1) and AR

(2) refers to the Arellano-Bond test for first-order and second-order serial correlation. Standard errors in parentheses ${ }^{*} p<0.10,{ }^{* *} p<0.05$, $* * * p<0.01$. 
Among CSP dimensions, we found that climate change (model 1), natural resource use (model 2), human capital (model 5) and corporate governance (model 8 ) have a negative and highly significant effect at the $1 \%$ level on CDS spreads, with coefficients of $-0.0099,-0.0095,-0.0140$ and -0.0102 , respectively. For each of these dimensions, a one standard deviation increase leads to a $2.5 \%$ $(2.54 \times-0.0099), 2.4 \%(2.51 \times-0.0095), 2.7 \%(1.98 \times-0.0140)$ and $2.5 \%(2.41 \times-0.0102)$ reduction in CDS spreads, respectively. The remaining CSP dimensions have an insignificant effect on credit risk.

\subsection{The Effects of Corporate Social Performance (CSP) Dimensions and Country Sustainability on Credit Risk}

To test our second hypothesis, Table 5 presents the results from the System GMM with Windmeijer (2005) corrected standard errors for the influence of country sustainability on the relationship between CSP dimensions and CDS spreads. The coefficients on the lagged dependent variable are negative and highly significant at the 1\% level. The coefficient on C_ESG is negative and significant in all models, except model (7) where it is insignificant. Across these different dimensions, at their mean values, we estimate that a one standard deviation increase in C_ESG leads to a reduction in CDS spreads of up to $2.7 \%$.

Then, we estimate the marginal effects of CSP dimensions across different values of country sustainability. These marginal effects are presented in Figure 1a-i. The results show that the marginal effects of climate change (model 1), human capital (model 5), corporate governance (model 8) and business ethics (model 9) are negative and significant for low values of country sustainability. However, the marginal effects of these CSP dimensions turn to be insignificant as the value of the country sustainability increases. In contrast, the results also show that the marginal effects of social opportunities (model 7) are negative and significant for high values of country sustainability. The remaining CSP dimensions appear to have an insignificant effect on credit risk regardless of the country sustainability value. Overall, the results suggest that country sustainability context matters in the relationship between CSP dimensions and credit risk.

\subsection{Robustness Checks}

In order to test for the robustness of our results, we used component measures of country sustainability as well as industry and country subsamples.

Table 6 presents the results from system GMM with Windmeijer (2005) corrected standard errors for the influence of pillar-level country sustainability variables on the relationship between CSP dimensions and CDS spreads. We interacted with CSP environmental dimensions with country environment risk (C_ENV) in models (1)-(4), CSP social dimensions with country social risk (C_SOC) in models (5)-(7), and CSP governance dimensions with country strategic governance (C_GOV) in models (8) and (9). The coefficients of the lagged dependent variable are negative and highly significant at the $1 \%$ level in all models. We found that for low values of country strategic governance risk, the effects on credit risk of corporate governance (model 8) and business ethics (model 9) are negative and significant; but are insignificant at high levels of country strategic governance risk. However, using the country environment risk and country social risk as an alternative to country sustainability renders the effect of respective CSP dimensions to be insignificant instead. For brevity purposes, we did not reproduce diagrams of the marginal effects here. 
Table 5. System GMM estimation results for the effects of corporate social performance (CSP) dimensions and their interaction with aggregate country sustainability on corporate default swap (CDS) spreads.

\begin{tabular}{|c|c|c|c|c|c|c|c|c|c|}
\hline & (1) & (2) & (3) & (4) & (5) & (6) & (7) & (8) & (9) \\
\hline$C D S_{i t-1}$ & $\begin{array}{c}0.7330 * * * \\
(0.056)\end{array}$ & $\begin{array}{c}0.7359 * * * \\
(0.060)\end{array}$ & $\begin{array}{c}0.7515^{* * *} \\
(0.058)\end{array}$ & $\begin{array}{c}0.6105^{* * *} \\
(0.063)\end{array}$ & $\begin{array}{c}0.7458 * * * \\
(0.055)\end{array}$ & $\begin{array}{c}0.6676^{* * *} \\
(0.061)\end{array}$ & $\begin{array}{c}0.8762 * * * \\
(0.069)\end{array}$ & $\begin{array}{c}0.7330 * * * \\
(0.055)\end{array}$ & $\begin{array}{c}0.7411^{* * *} \\
(0.058)\end{array}$ \\
\hline C_ESG & $\begin{array}{c}-0.0365 \text { *** } \\
(0.010)\end{array}$ & $\begin{array}{c}-0.0166^{* *} \\
(0.008)\end{array}$ & $\begin{array}{c}-0.0214 \text { ** } \\
(0.010)\end{array}$ & $\begin{array}{c}-0.0435^{* *} \\
(0.018)\end{array}$ & $\begin{array}{c}-0.0214^{* * *} \\
(0.008)\end{array}$ & $\begin{array}{c}-0.0238^{* *} \\
(0.011)\end{array}$ & $\begin{array}{l}0.0253 \\
(0.018)\end{array}$ & $\begin{array}{c}-0.0310^{* * * *} \\
(0.010)\end{array}$ & $\begin{array}{c}-0.0304^{* * *} \\
(0.010)\end{array}$ \\
\hline Dimension & $\begin{array}{c}-0.1685^{* * *} \\
(0.058)\end{array}$ & $\begin{array}{c}-0.0253 \\
(0.058)\end{array}$ & $\begin{array}{c}-0.0713 \\
(0.064)\end{array}$ & $\begin{array}{c}-0.1692 \\
(0.135)\end{array}$ & $\begin{array}{c}-0.0994 \text { * } \\
(0.055)\end{array}$ & $\begin{array}{c}-0.0545 \\
(0.094)\end{array}$ & $\begin{array}{l}0.1381 \\
(0.146)\end{array}$ & $\begin{array}{c}-0.1483^{* *} \\
(0.060)\end{array}$ & $\begin{array}{c}-0.2010 * \\
(0.103)\end{array}$ \\
\hline Interaction & $\begin{array}{c}0.0029^{* * *} \\
(0.001)\end{array}$ & $\begin{array}{l}0.0003 \\
(0.001)\end{array}$ & $\begin{array}{l}0.0013 \\
(0.001)\end{array}$ & $\begin{array}{l}0.0030 \\
(0.002)\end{array}$ & $\begin{array}{l}0.0016 \\
(0.001)\end{array}$ & $\begin{array}{l}0.0009 \\
(0.002)\end{array}$ & $\begin{array}{l}-0.0027 \\
(0.003)\end{array}$ & $\begin{array}{c}0.0025^{* *} \\
(0.001)\end{array}$ & $\begin{array}{c}0.0035 * \\
(0.002)\end{array}$ \\
\hline DTD & $\begin{array}{c}-0.0086^{*} \\
(0.005)\end{array}$ & $\begin{array}{c}-0.0095 * \\
(0.005)\end{array}$ & $\begin{array}{l}-0.0077 \\
(0.005)\end{array}$ & $\begin{array}{c}-0.0058 \\
(0.008)\end{array}$ & $\begin{array}{c}-0.0081 * \\
(0.005)\end{array}$ & $\begin{array}{c}-0.0038 \\
(0.006)\end{array}$ & $\begin{array}{l}0.0067 \\
(0.007)\end{array}$ & $\begin{array}{c}-0.0090 * \\
(0.005)\end{array}$ & $\begin{array}{c}-0.0045 \\
(0.006)\end{array}$ \\
\hline Size & $\begin{array}{c}-0.0568^{* * *} \\
(0.012)\end{array}$ & $\begin{array}{c}-0.0560 * * * \\
(0.013)\end{array}$ & $\begin{array}{c}-0.0600 * * * \\
(0.013)\end{array}$ & $\begin{array}{c}-0.0966^{* * *} \\
(0.018)\end{array}$ & $\begin{array}{c}-0.0602 * * * \\
(0.013)\end{array}$ & $\begin{array}{c}-0.0855^{* * * *} \\
(0.018)\end{array}$ & $\begin{array}{c}-0.0219 \\
(0.022)\end{array}$ & $\begin{array}{c}-0.0625^{* * *} \\
(0.013)\end{array}$ & $\begin{array}{c}-0.0553 * * * \\
(0.015)\end{array}$ \\
\hline$T D / T A$ & $\begin{array}{c}0.2197 * * * \\
(0.083)\end{array}$ & $\begin{array}{c}0.1936^{* *} \\
(0.085)\end{array}$ & $\begin{array}{c}0.2132 * * \\
(0.083)\end{array}$ & $\begin{array}{c}0.3322 * * \\
(0.135)\end{array}$ & $\begin{array}{c}0.2169 * * * \\
(0.079)\end{array}$ & $\begin{array}{c}0.3385^{* * * *} \\
(0.117)\end{array}$ & $\begin{array}{l}0.2272 \\
(0.149)\end{array}$ & $\begin{array}{c}0.2113^{* * * *} \\
(0.081)\end{array}$ & $\begin{array}{c}0.2328 * * \\
(0.117)\end{array}$ \\
\hline$S T / L T$ & $\begin{array}{c}-0.0934 \\
(0.079)\end{array}$ & $\begin{array}{l}-0.1096 \\
(0.079)\end{array}$ & $\begin{array}{c}-0.0973 \\
(0.079)\end{array}$ & $\begin{array}{l}0.0317 \\
(0.112)\end{array}$ & $\begin{array}{c}-0.0665 \\
(0.074)\end{array}$ & $\begin{array}{c}-0.1913 \\
(0.121)\end{array}$ & $\begin{array}{c}-0.1689 \\
(0.190)\end{array}$ & $\begin{array}{c}-0.0832 \\
(0.077)\end{array}$ & $\begin{array}{c}-0.0835 \\
(0.111)\end{array}$ \\
\hline$M V / B V$ & $\begin{array}{c}-0.0015 \\
(0.001)\end{array}$ & $\begin{array}{c}-0.0018 \\
(0.001)\end{array}$ & $\begin{array}{l}-0.0017 \\
(0.001)\end{array}$ & $\begin{array}{l}0.0030 \\
(0.002)\end{array}$ & $\begin{array}{c}-0.0017^{*} \\
(0.001)\end{array}$ & $\begin{array}{l}-0.0012 \\
(0.001)\end{array}$ & $\begin{array}{c}-0.0006 \\
(0.002)\end{array}$ & $\begin{array}{c}-0.0017^{*} \\
(0.001)\end{array}$ & $\begin{array}{c}-0.0033^{*} \\
(0.002)\end{array}$ \\
\hline Margin & $\begin{array}{c}0.0016^{*} \\
(0.001)\end{array}$ & $\begin{array}{c}0.0014^{*} \\
(0.001)\end{array}$ & $\begin{array}{l}0.0013 \\
(0.001)\end{array}$ & $\begin{array}{l}0.0015 \\
(0.001)\end{array}$ & $\begin{array}{l}0.0011 \\
(0.001)\end{array}$ & $\begin{array}{l}-0.0012 \\
(0.001)\end{array}$ & $\begin{array}{c}-0.0001 \\
(0.003)\end{array}$ & $\begin{array}{l}0.0014^{*} \\
(0.001)\end{array}$ & $\begin{array}{c}0.0036^{* * *} \\
(0.001)\end{array}$ \\
\hline$C A / C L$ & $\begin{array}{c}0.0216^{* * *} \\
(0.009)\end{array}$ & $\begin{array}{l}0.0156 \\
(0.009)\end{array}$ & $\begin{array}{c}0.0218^{* *} \\
(0.009)\end{array}$ & $\begin{array}{c}0.0291 \text { ** } \\
(0.014)\end{array}$ & $\begin{array}{c}0.0225^{* *} \\
(0.009)\end{array}$ & $\begin{array}{l}0.0035 \\
(0.014)\end{array}$ & $\begin{array}{c}-0.0093 \\
(0.027)\end{array}$ & $\begin{array}{c}0.0186^{* *} \\
(0.009)\end{array}$ & $\begin{array}{l}0.0024 \\
(0.016)\end{array}$ \\
\hline CASH/TA & $\begin{array}{c}0.3234^{*} \\
(0.185)\end{array}$ & $\begin{array}{c}0.5065^{* * * *} \\
(0.182)\end{array}$ & $\begin{array}{c}0.5167^{* * * *} \\
(0.177)\end{array}$ & $\begin{array}{l}0.0556 \\
(0.287)\end{array}$ & $\begin{array}{c}0.4883^{* * *} \\
(0.176)\end{array}$ & $\begin{array}{l}-0.0357 \\
(0.267)\end{array}$ & $\begin{array}{c}-0.4643 \\
(0.397)\end{array}$ & $\begin{array}{c}0.3966^{* *} \\
(0.180)\end{array}$ & $\begin{array}{c}0.5265^{*} \\
(0.286)\end{array}$ \\
\hline STKVOL & $\begin{array}{c}0.4774^{* * *} \\
(0.175)\end{array}$ & $\begin{array}{c}0.5073^{* * *} \\
(0.189)\end{array}$ & $\begin{array}{c}0.4674 * * * \\
(0.174)\end{array}$ & $\begin{array}{c}0.5951^{* *} \\
(0.268)\end{array}$ & $\begin{array}{c}0.4680 * * * \\
(0.174)\end{array}$ & $\begin{array}{c}0.7451^{* * *} \\
(0.221)\end{array}$ & $\begin{array}{l}0.4564 \\
(0.393)\end{array}$ & $\begin{array}{c}0.5101 * * * \\
(0.177)\end{array}$ & $\begin{array}{c}0.7515^{* * *} \\
(0.239)\end{array}$ \\
\hline$Y P C$ & $\begin{array}{l}0.0119 \\
(0.035)\end{array}$ & $\begin{array}{l}0.0002 \\
(0.040)\end{array}$ & $\begin{array}{c}-0.0069 \\
(0.043)\end{array}$ & $\begin{array}{c}-0.0813 \\
(0.076)\end{array}$ & $\begin{array}{l}0.0111 \\
(0.031)\end{array}$ & $\begin{array}{l}0.0501 \\
(0.060)\end{array}$ & $\begin{array}{l}0.0250 \\
(0.078)\end{array}$ & $\begin{array}{l}0.0056 \\
(0.032)\end{array}$ & $\begin{array}{l}0.0321 \\
(0.042)\end{array}$ \\
\hline$\Delta Y$ & $\begin{array}{c}0.0286^{* * *} \\
(0.009)\end{array}$ & $\begin{array}{c}0.0258^{* * * *} \\
(0.009)\end{array}$ & $\begin{array}{c}0.0297^{* * *} \\
(0.009)\end{array}$ & $\begin{array}{c}0.0495^{* * *} \\
(0.014)\end{array}$ & $\begin{array}{c}0.0293 * * * \\
(0.009)\end{array}$ & $\begin{array}{c}0.0358^{* *} \\
(0.015)\end{array}$ & $\begin{array}{c}-0.0277 \\
(0.021)\end{array}$ & $\begin{array}{c}0.0343^{* * * *} \\
(0.009)\end{array}$ & $\begin{array}{c}0.0368^{* * *} \\
(0.013)\end{array}$ \\
\hline MKTVOL & $\begin{array}{c}-9.5820 * * * \\
(1.572)\end{array}$ & $\begin{array}{c}-9.3960 * * * \\
(1.747)\end{array}$ & $\begin{array}{c}-9.4418^{* * *} \\
(1.695)\end{array}$ & $\begin{array}{c}-10.0426^{* * * *} \\
(2.184)\end{array}$ & $\begin{array}{c}-9.1626^{* * *} \\
(1.540)\end{array}$ & $\begin{array}{c}-11.5012 * * * \\
(1.928)\end{array}$ & $\begin{array}{c}-9.4207^{* * *} \\
(3.297)\end{array}$ & $\begin{array}{c}-9.4259^{* * *} \\
(1.621)\end{array}$ & $\begin{array}{c}-7.1737^{* * *} \\
(1.880)\end{array}$ \\
\hline Sovereign & $\begin{array}{l}0.0009 \\
(0.019)\end{array}$ & $\begin{array}{c}-0.0066 \\
(0.019)\end{array}$ & $\begin{array}{c}-0.0053 \\
(0.019)\end{array}$ & $\begin{array}{c}-0.0279 \\
(0.032)\end{array}$ & $\begin{array}{c}-0.0034 \\
(0.018)\end{array}$ & $\begin{array}{l}0.0322 \\
(0.032)\end{array}$ & $\begin{array}{c}0.0969 * * \\
(0.045)\end{array}$ & $\begin{array}{c}-0.0042 \\
(0.018)\end{array}$ & $\begin{array}{c}-0.0218 \\
(0.025)\end{array}$ \\
\hline $\begin{array}{l}\text { Year Effects } \\
\text { Constant }\end{array}$ & $\begin{array}{c}\text { Yes } \\
3.6038^{* * *} \\
(0.795)\end{array}$ & $\begin{array}{c}\text { Yes } \\
2.6026^{* * *} \\
(0.720)\end{array}$ & $\begin{array}{c}\text { Yes } \\
2.8554^{* * *} \\
(0.801)\end{array}$ & $\begin{array}{c}\text { Yes } \\
5.8183^{* * *} \\
(1.307)\end{array}$ & $\begin{array}{c}\text { Yes } \\
2.7273^{* * *} \\
(0.695)\end{array}$ & $\begin{array}{c}\text { Yes } \\
2.9257^{* * *} \\
(1.123)\end{array}$ & $\begin{array}{c}\text { Yes } \\
-1.1193 \\
(1.668)\end{array}$ & $\begin{array}{c}\text { Yes } \\
3.4241 * * * \\
(0.818)\end{array}$ & $\begin{array}{c}\text { Yes } \\
2.7919^{* * *} \\
(0.955)\end{array}$ \\
\hline
\end{tabular}


Table 5. Cont.

\begin{tabular}{|c|c|c|c|c|c|c|c|c|c|}
\hline & (1) & (2) & (3) & (4) & (5) & (6) & (7) & (8) & (9) \\
\hline \# of Observations & 2050 & 1954 & 1937 & 926 & 2075 & 1127 & 316 & 2091 & 753 \\
\hline \# of Firms & 582 & 557 & 548 & 266 & 589 & 349 & 98 & 591 & 223 \\
\hline \# of Instruments & 29 & 29 & 29 & 29 & 29 & 29 & 29 & 29 & 29 \\
\hline Hansen Test & 0.0806 & 0.2625 & 0.2175 & 0.0705 & 0.2593 & 0.6357 & 0.4667 & 0.2800 & 0.0360 \\
\hline AR (1) & 0.0000 & 0.0000 & 0.0000 & 0.0000 & 0.0000 & 0.0000 & 0.0000 & 0.0000 & 0.0000 \\
\hline AR (2) & 0.4258 & 0.3591 & 0.8952 & 0.3436 & 0.2498 & 0.4381 & 0.6120 & 0.3013 & 0.4381 \\
\hline
\end{tabular}

Notes: this table presents the System GMM estimation results on CDS spreads for the effects of CSP dimensions: (1) climate change; (2) natural resource use; (3) waste management;

(4) environmental opportunities; (5) human capital; (6) product safety; (7) social opportunities; (8) corporate governance; and (9) business ethics. The interaction term refers to the interaction between C_ESG and the respective CSP dimension. \# refers to the number. AR (1) and AR (2) refers to the Arellano-Bond test for first-order and second-order serial correlation. Standard errors are in parentheses $* x<0.10, * * p<0.05, * * * x<0.01$ 


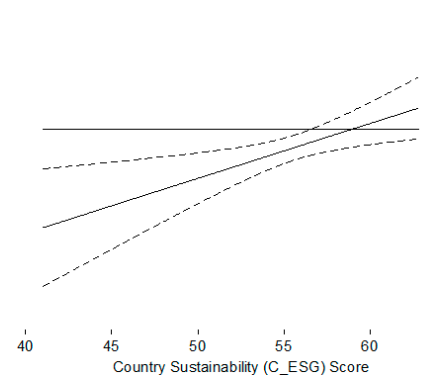

(a)

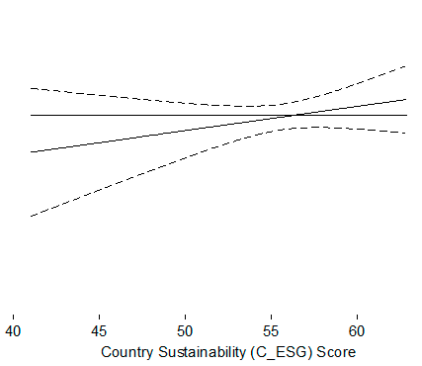

(c)

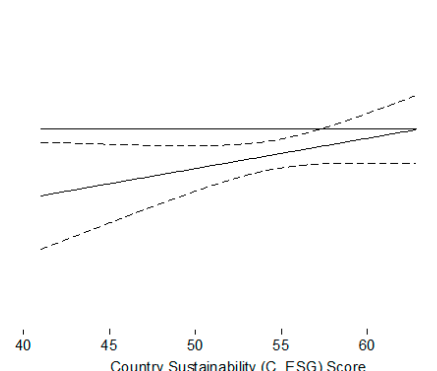

(e)

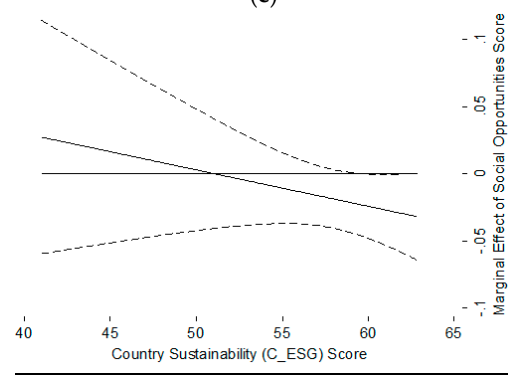

(g)

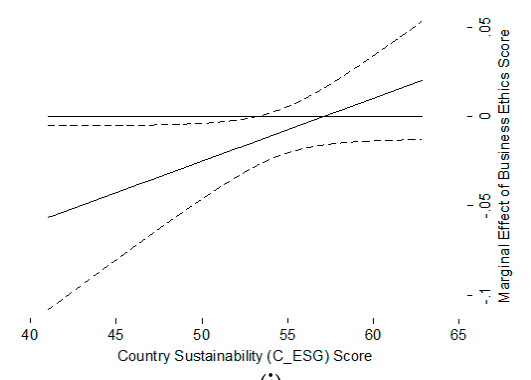

(i)

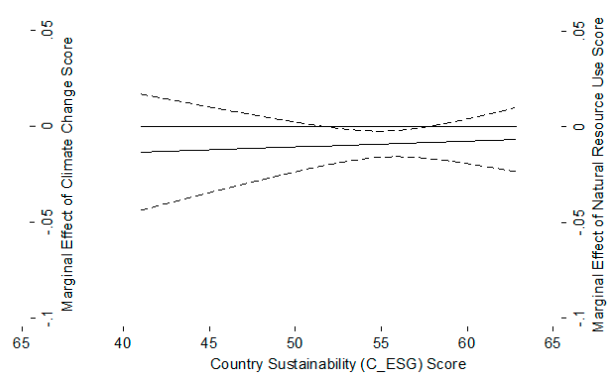

(b)
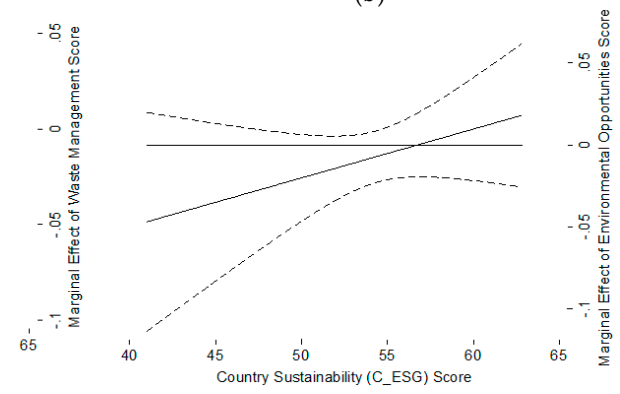

(d)

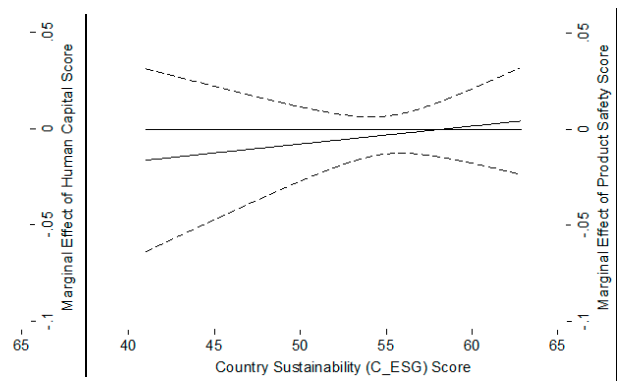

(f)

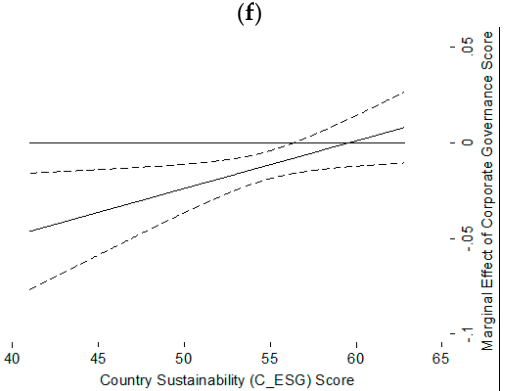

(h)

Figure 1. This figure shows the marginal effects on credit risk across different values of country sustainability (C_ESG) for the following corporate social performance (CSP) dimensions: (a) climate change; (b) natural resource use; (c) waste management; (d) environmental opportunities; (e) human capital; (f) product safety; (g) social opportunities; (h) corporate governance; and (i) business ethics. 
Table 6. System GMM estimation results for effects of corporate social performance (CSP) dimensions and its interaction with pillar-level country sustainability on corporate default swap (CDS) spreads.

\begin{tabular}{|c|c|c|c|c|c|c|c|c|c|}
\hline & (1) & (2) & (3) & (4) & (5) & (6) & (7) & (8) & (9) \\
\hline$C D S_{i t-1}$ & $\begin{array}{c}0.7224^{* * *} \\
(0.056)\end{array}$ & $\begin{array}{c}0.7250 * * * \\
(0.059)\end{array}$ & $\begin{array}{c}0.7318^{* * *} \\
(0.056)\end{array}$ & $\begin{array}{c}0.6124^{* * *} \\
(0.071)\end{array}$ & $\begin{array}{c}0.7359^{* * *} \\
(0.055)\end{array}$ & $\begin{array}{c}0.6635^{* * *} \\
(0.062)\end{array}$ & $\begin{array}{c}0.8594^{* * *} \\
(0.077)\end{array}$ & $\begin{array}{c}0.7389^{* * *} \\
(0.052)\end{array}$ & $\begin{array}{c}0.7151^{* * *} \\
(0.062)\end{array}$ \\
\hline C_ENV & $\begin{array}{c}0.0094^{* * *} \\
(0.003)\end{array}$ & $\begin{array}{c}0.0097^{* * * *} \\
(0.003)\end{array}$ & $\begin{array}{c}0.0097^{* * *} \\
(0.003)\end{array}$ & $\begin{array}{l}0.0026 \\
(0.005)\end{array}$ & & & & & \\
\hline C_SOC & & & & & $\begin{array}{c}-0.0154^{* * *} \\
(0.005)\end{array}$ & $\begin{array}{c}-0.0139 * \\
(0.007)\end{array}$ & $\begin{array}{c}-0.0216 \\
(0.021)\end{array}$ & & \\
\hline C_GOV & & & & & & & & $\begin{array}{c}-0.0114^{* * *} \\
(0.004)\end{array}$ & $\begin{array}{c}-0.0127^{* *} \\
(0.005)\end{array}$ \\
\hline Dimension & $\begin{array}{l}0.0164 \\
(0.018)\end{array}$ & $\begin{array}{c}0.0343 * \\
(0.019)\end{array}$ & $\begin{array}{c}0.0327^{* *} \\
(0.016)\end{array}$ & $\begin{array}{c}-0.0150 \\
(0.041)\end{array}$ & $\begin{array}{c}-0.0186 \\
(0.041)\end{array}$ & $\begin{array}{l}0.0464 \\
(0.064)\end{array}$ & $\begin{array}{c}-0.1941 \\
(0.169)\end{array}$ & $\begin{array}{c}-0.0768^{* *} \\
(0.033)\end{array}$ & $\begin{array}{c}-0.1316^{*} \\
(0.074)\end{array}$ \\
\hline Interaction & $\begin{array}{c}-0.0005 \\
(0.000)\end{array}$ & $\begin{array}{c}-0.0009^{* *} \\
(0.000)\end{array}$ & $\begin{array}{c}-0.0007 * \\
(0.000)\end{array}$ & $\begin{array}{l}0.0002 \\
(0.001)\end{array}$ & $\begin{array}{l}0.0002 \\
(0.001)\end{array}$ & $\begin{array}{c}-0.0009 \\
(0.001)\end{array}$ & $\begin{array}{l}0.0033 \\
(0.003)\end{array}$ & $\begin{array}{c}0.0009 * * \\
(0.000)\end{array}$ & $\begin{array}{l}0.0016 \\
(0.001)\end{array}$ \\
\hline DTD & $\begin{array}{c}-0.0117^{* *} \\
(0.005)\end{array}$ & $\begin{array}{c}-0.0120 * * \\
(0.005)\end{array}$ & $\begin{array}{c}-0.0109^{* *} \\
(0.005)\end{array}$ & $\begin{array}{c}-0.0116 \\
(0.011)\end{array}$ & $\begin{array}{c}-0.0146^{* * * *} \\
(0.005)\end{array}$ & $\begin{array}{c}-0.0094 \\
(0.006)\end{array}$ & $\begin{array}{l}0.0034 \\
(0.007)\end{array}$ & $\begin{array}{c}-0.0087^{*} \\
(0.005)\end{array}$ & $\begin{array}{l}-0.0054 \\
(0.006)\end{array}$ \\
\hline Size & $\begin{array}{c}-0.06111^{* * *} \\
(0.012)\end{array}$ & $\begin{array}{c}-0.0575 * * * \\
(0.013)\end{array}$ & $\begin{array}{c}-0.0632 * * * \\
(0.012)\end{array}$ & $\begin{array}{c}-0.0907^{* * *} \\
(0.018)\end{array}$ & $\begin{array}{c}-0.0577 * * * \\
(0.012)\end{array}$ & $\begin{array}{c}-0.0805 * * * \\
(0.017)\end{array}$ & $\begin{array}{l}-0.0308 \\
(0.025)\end{array}$ & $\begin{array}{c}-0.0636^{* * *} \\
(0.012)\end{array}$ & $\begin{array}{c}-0.0643 \text { *** } \\
(0.016)\end{array}$ \\
\hline$T D / T A$ & $\begin{array}{c}0.1538^{* * *} \\
(0.074)\end{array}$ & $\begin{array}{c}0.1345^{*} \\
(0.075)\end{array}$ & $\begin{array}{c}0.1602^{* *} \\
(0.073)\end{array}$ & $\begin{array}{l}0.2049 \\
(0.125)\end{array}$ & $\begin{array}{c}0.1914 * * * \\
(0.074)\end{array}$ & $\begin{array}{c}0.3166 * * * \\
(0.111)\end{array}$ & $\begin{array}{l}0.1720 \\
(0.151)\end{array}$ & $\begin{array}{c}0.1720 \text { ** } \\
(0.073)\end{array}$ & $\begin{array}{l}0.1849 \\
(0.112)\end{array}$ \\
\hline$S T / L T$ & $\begin{array}{c}-0.0827 \\
(0.082)\end{array}$ & $\begin{array}{c}-0.0967 \\
(0.080)\end{array}$ & $\begin{array}{c}-0.0857 \\
(0.080)\end{array}$ & $\begin{array}{l}-0.0147 \\
(0.127)\end{array}$ & $\begin{array}{c}-0.0596 \\
(0.076)\end{array}$ & $\begin{array}{c}-0.1695 \\
(0.118)\end{array}$ & $\begin{array}{l}-0.1666 \\
(0.200)\end{array}$ & $\begin{array}{c}-0.0885 \\
(0.079)\end{array}$ & $\begin{array}{l}-0.1311 \\
(0.122)\end{array}$ \\
\hline$M V / B V$ & $\begin{array}{c}-0.0014 \\
(0.001)\end{array}$ & $\begin{array}{c}-0.0017 \\
(0.001)\end{array}$ & $\begin{array}{c}-0.0017 \\
(0.001)\end{array}$ & $\begin{array}{l}0.0021 \\
(0.002)\end{array}$ & $\begin{array}{c}-0.0017^{*} \\
(0.001)\end{array}$ & $\begin{array}{c}-0.0013 \\
(0.001)\end{array}$ & $\begin{array}{l}-0.0006 \\
(0.002)\end{array}$ & $\begin{array}{c}-0.0016^{*} \\
(0.001)\end{array}$ & $\begin{array}{c}-0.0034^{*} \\
(0.002)\end{array}$ \\
\hline Margin & $\begin{array}{c}0.0023^{* * *} \\
(0.001)\end{array}$ & $\begin{array}{c}0.0022 * * * \\
(0.001)\end{array}$ & $\begin{array}{c}0.0019^{* *} \\
(0.001)\end{array}$ & $\begin{array}{c}0.0043^{* * *} \\
(0.002)\end{array}$ & $\begin{array}{l}0.0012 \\
(0.001)\end{array}$ & $\begin{array}{c}-0.0014 \\
(0.001)\end{array}$ & $\begin{array}{l}0.0019 \\
(0.003)\end{array}$ & $\begin{array}{c}0.0019^{* *} \\
(0.001)\end{array}$ & $\begin{array}{c}0.0051^{* * *} \\
(0.001)\end{array}$ \\
\hline$C A / C L$ & $\begin{array}{l}0.0157 \\
(0.010)\end{array}$ & $\begin{array}{l}0.0086 \\
(0.011)\end{array}$ & $\begin{array}{l}0.0159 \\
(0.010)\end{array}$ & $\begin{array}{c}0.0335^{* * *} \\
(0.016)\end{array}$ & $\begin{array}{l}0.0163^{*} \\
(0.009)\end{array}$ & $\begin{array}{c}-0.0061 \\
(0.015)\end{array}$ & $\begin{array}{l}-0.0193 \\
(0.032)\end{array}$ & $\begin{array}{l}0.0156 \\
(0.010)\end{array}$ & $\begin{array}{l}-0.0016 \\
(0.017)\end{array}$ \\
\hline CASH/TA & $\begin{array}{l}0.1160 \\
(0.201)\end{array}$ & $\begin{array}{l}0.3081 \\
(0.196)\end{array}$ & $\begin{array}{l}0.2587 \\
(0.197)\end{array}$ & $\begin{array}{c}-0.3635 \\
(0.335)\end{array}$ & $\begin{array}{c}0.4930^{* * *} \\
(0.176)\end{array}$ & $\begin{array}{l}0.0347 \\
(0.256)\end{array}$ & $\begin{array}{c}-0.5638 \\
(0.458)\end{array}$ & $\begin{array}{l}0.3027 \\
(0.184)\end{array}$ & $\begin{array}{l}0.2541 \\
(0.290)\end{array}$ \\
\hline STKVOL & $\begin{array}{c}0.4689 * * * \\
(0.174)\end{array}$ & $\begin{array}{c}0.4991 * * * \\
(0.187)\end{array}$ & $\begin{array}{c}0.4812 * * * \\
(0.173)\end{array}$ & $\begin{array}{c}0.5644^{*} \\
(0.289)\end{array}$ & $\begin{array}{c}0.4323^{* * *} \\
(0.171)\end{array}$ & $\begin{array}{c}0.6959 * * * \\
(0.216)\end{array}$ & $\begin{array}{l}0.4554 \\
(0.409)\end{array}$ & $\begin{array}{c}0.4729 * * * \\
(0.169)\end{array}$ & $\begin{array}{c}0.8470^{* * *} \\
(0.239)\end{array}$ \\
\hline$Y P C$ & $\begin{array}{c}-0.0971 * * * \\
(0.031)\end{array}$ & $\begin{array}{c}-0.0957^{* * *} \\
(0.035)\end{array}$ & $\begin{array}{c}-0.1168 * * * * \\
(0.037)\end{array}$ & $\begin{array}{c}-0.2267^{* * *} \\
(0.075)\end{array}$ & $\begin{array}{c}-0.1030 * * * * \\
(0.033)\end{array}$ & $\begin{array}{c}-0.1043 \\
(0.064)\end{array}$ & $\begin{array}{l}0.0209 \\
(0.080)\end{array}$ & $\begin{array}{l}0.0297 \\
(0.036)\end{array}$ & $\begin{array}{l}0.0826 \\
(0.051)\end{array}$ \\
\hline$\Delta Y$ & $\begin{array}{c}0.0177^{* *} \\
(0.008)\end{array}$ & $\begin{array}{c}0.0162 * * \\
(0.008)\end{array}$ & $\begin{array}{c}0.0194^{* *} \\
(0.008)\end{array}$ & $\begin{array}{c}0.0413 * * * \\
(0.015)\end{array}$ & $\begin{array}{c}0.0169^{* *} \\
(0.008)\end{array}$ & $\begin{array}{l}0.0160 \\
(0.014)\end{array}$ & $\begin{array}{c}-0.0199 \\
(0.022)\end{array}$ & $\begin{array}{c}0.0314^{* * * *} \\
(0.008)\end{array}$ & $\begin{array}{c}0.0357^{* * *} \\
(0.012)\end{array}$ \\
\hline MKTVOL & $\begin{array}{c}-10.8221 \\
(1.799)\end{array}$ & $\begin{array}{c}-11.4893 * * * \\
(2.117)\end{array}$ & $\begin{array}{c}-11.6094 * * * \\
(1.976)\end{array}$ & $\begin{array}{c}-12.5057^{* * * *} \\
(2.355)\end{array}$ & $\begin{array}{c}-9.9901 * * * \\
(1.745)\end{array}$ & $\begin{array}{c}-12.8498^{* * *} \\
(1.982)\end{array}$ & $\begin{array}{c}-8.0197 * * \\
(3.450)\end{array}$ & $\begin{array}{c}-10.8015 * * * \\
(1.880)\end{array}$ & $\begin{array}{l}-9.8122 * * * * \\
(2.074)\end{array}$ \\
\hline Sovereign & $\begin{array}{l}0.0328 \\
(0.021)\end{array}$ & $\begin{array}{l}0.0287 \\
(0.022)\end{array}$ & $\begin{array}{l}0.0315 \\
(0.022)\end{array}$ & $\begin{array}{l}0.0443 \\
(0.037)\end{array}$ & $\begin{array}{c}-0.0192 \\
(0.019)\end{array}$ & $\begin{array}{l}0.0142 \\
(0.031)\end{array}$ & $\begin{array}{c}0.0857 * \\
(0.047)\end{array}$ & $\begin{array}{l}0.0142 \\
(0.018)\end{array}$ & $\begin{array}{l}0.0096 \\
(0.025)\end{array}$ \\
\hline $\begin{array}{l}\text { Year Effects } \\
\text { Constant }\end{array}$ & $\begin{array}{c}\text { Yes } \\
2.3949^{* * *} \\
(0.553)\end{array}$ & $\begin{array}{c}\text { Yes } \\
2.3395^{* * *} \\
(0.607)\end{array}$ & $\begin{array}{c}\text { Yes } \\
2.5175^{* * *} \\
(0.623)\end{array}$ & $\begin{array}{c}\text { Yes } \\
4.7127^{* * *} \\
(1.051)\end{array}$ & $\begin{array}{c}\text { Yes } \\
3.7316^{* * *} \\
(0.811)\end{array}$ & $\begin{array}{c}\text { Yes } \\
4.1352^{* * *} \\
(1.283)\end{array}$ & $\begin{array}{c}\text { Yes } \\
1.6888 \\
(1.960)\end{array}$ & $\begin{array}{c}\text { Yes } \\
2.2646^{* * *} \\
(0.522)\end{array}$ & $\begin{array}{c}\text { Yes } \\
1.7090^{* *} \\
(0.731)\end{array}$ \\
\hline
\end{tabular}


Table 6. Cont.

\begin{tabular}{|c|c|c|c|c|c|c|c|c|c|}
\hline & (1) & (2) & (3) & (4) & (5) & (6) & (7) & (8) & (9) \\
\hline \# of Observations & 2050 & 1954 & 1937 & 926 & 2075 & 1127 & 316 & 2091 & 753 \\
\hline \# of Firms & 582 & 557 & 548 & 266 & 589 & 349 & 98 & 591 & 223 \\
\hline \# of Instruments & 29 & 29 & 29 & 29 & 29 & 29 & 29 & 29 & 29 \\
\hline Hansen Test & 0.1092 & 0.3834 & 0.4409 & 0.0492 & 0.2482 & 0.6428 & 0.4554 & 0.3411 & 0.0949 \\
\hline AR (2) & 0.5133 & 0.4213 & 0.8282 & 0.2419 & 0.2048 & 0.4070 & 0.7006 & 0.3301 & 0.5004 \\
\hline
\end{tabular}

Notes: this table presents the System GMM estimation results on CDS spreads for the effects of CSP dimensions: (1) climate change; (2) natural resource use; (3) waste management;

(4) environmental opportunities; (5) human capital; (6) product safety; (7) social opportunities; (8) corporate governance; (9) business ethics. The interaction term refers to the interaction

between the CSP dimension and the respective pillar-level country sustainability measure: C_ENV for models (1), (2) and (3); C_SOC for models (4), (5), and (6) and C_GOV for models (8)

and (9). \# refers to the number. AR (1) and AR (2) refers to the Arellano-Bond test for first-order and second-order serial correlation. Standard errors in parentheses * $p<0.10$, ${ }^{* *} p<0.05$, and (9). \# 
We also explored the effects of various CSP dimensions across different industry subsamples based on MSCI's sectoral classification, and found that the results were broadly consistent using System GMM. Estimation results using alternative econometric specifications such as fixed effects also show broadly similar qualitative findings. For brevity reasons, these results are not reproduced here.

\section{Conclusions}

This paper examined the effects of CSP dimensions on credit default swap (CDS) spreads using a sample of 2094 global non-financial firms for the period 2013-2016. We derived several notable conclusions. Firstly, we found that the effect of different CSP dimensions on credit risk is not uniform. In particular, the findings suggest risk-reducing effects resulting from better performance across the following CSP dimensions: climate change; natural resource use; human capital; and corporate governance. This implies that corporate sustainability leaders in these dimensions are relatively more creditworthy than their peers. However, caution needs to be exercised as the extent to which these disaggregated dimensions affect credit risk differs across industries.

Secondly, we find that country sustainability matters in the nexus between corporate sustainability and credit risk, are consistent with recent literature (Hoepner et al. 2016; Stellner et al. 2015). Corporations are embedded within broader social structures, and the results are consistent with the wider empirical literature which finds that the financial benefits of corporate social responsibility (CSR) activities are greater in the presence of institutional voids (El Ghoul et al. 2017; Su et al. 2016; Xiao et al. 2018). This also supports the proposition that as societal expectations about a firm's environmental and social responsibilities increase, improved CSP is unlikely to bring about financial benefits (Barnett 2007). In countries with lower levels of sustainability performance, CSR activities can reduce transaction costs and increase access to capital, in the form of social capital and enhanced reputations which can be difficult to obtain. In contrast, corporations that do not meet higher societal norms and expectations of environmental integrity and social equity in countries with high levels of sustainability performance, may negatively impact their legitimacy. These firms would be more susceptible to the higher costs associated with being exposed to legal, regulatory, and reputational risks, and in turn may affect the financial performance through larger credit spreads. Given the importance of the external context in which a firm resides in credit risk, it may be difficult to obtain a one-size-fits-all policy or credit-relevant standardization on sustainability factors. The implication of this finding is that countries that improve their sustainability performance can also provide financial stability to businesses that are domiciled within them.

Thirdly, independently of the country sustainability context, we found that the results were robust for corporate governance, similarly to in other studies (Kiesel and Lücke 2019). Our interpretation of this result is that the benefits of CSP improvements in terms of corporate credit risk are primarily achieved by meeting governance best practices, which helps build up internal resources and intangible benefits. This reduces cash flow volatility and improves the firm's credit risk profile. As a result, this implies that corporations should strengthen governance frameworks and procedures, prior to embarking on environmental and social objectives.

There are several limitations of the present study. The first limitation concerns the main focus variables: corporate- and country-level sustainability dimensions. It is difficult to obtain a CSP measure that can be universally agreed upon by various stakeholders, who may have competing interpretations and prioritizations of sustainability and materiality. Given the potential for differences in interpretation, it is unlikely that different stakeholders would share the same assessment of CSP with MSCI ESG, which only prioritizes the financial value of ESG issues for corporations. Consequently, the question of whether exclusive focus on the financially material aspects of corporate responsibility can adequately contribute towards sustainable development is an important issue, but beyond the scope of this paper. As corporate and country sustainability data becomes increasingly made available, and further consensus emerges regarding their precise scope and definitions, future research could replicate the current study to test whether the results hold with different samples. The second limitation is the 
related to the use of CDS spreads as a measure of credit risk. Though this provided our study with a market-based measure of credit risk, many companies were excluded as they did not choose to enter the CDS market. Hence, further research could also explore the relationship between sustainability and credit risk for other institutions such as micro, small, and medium-sized enterprises (MSMEs) using other proxy measures for credit risk. Finally, the top-down approach taken in this paper can be complemented with bottom-up approaches from different industries and regions. For example, the Natural Capital Finance Alliance has recently developed a sector-specific guide that enables financial institutions to conduct natural capital credit risk assessment across different agricultural sectors and geographies.

Author Contributions: Conceptualization, L.A.R. and A.N.; methodology, L.A.R., M.H.I. and A.N.; software, L.A.R., M.H.I. and A.N.; validation, L.A.R., M.H.I. \& A.N.; formal analysis, L.A.R.; investigation, L.A.R., M.H.I. and A.N.; resources, L.A.R. and A.N.; data curation, L.A.R. and A.N.; writing-original draft preparation, L.A.R.; writing - review and editing, M.H.I. and A.N.; visualization, L.A.R. and M.H.I.; supervision, M.H.I. and A.N.; project administration, L.A.R., M.H.I. and A.N. All authors have read and agreed to the published version of the manuscript.

Funding: This research received no external funding.

Acknowledgments: For kind assistance with the graphical abstract, the authors thank Mohamed Syazwan $\mathrm{Ab}$ Talib. For helpful comments and suggestions, the authors thanks three anonymous reviewers. The usual disclaimer applies.

Conflicts of Interest: The authors declare no conflict of interest.

\section{References}

Alali, Fatima, Asokan Anandarajan, and Wei Jiang. 2012. The Effect of Corporate Governance on Firm's Credit Ratings: Further Evidence Using Governance Score in the United States. Accounting \& Finance 52: 291-312.

Ali, Saerat, Benjamin Liu, and Jen Je Su. 2018. Does Corporate Governance Quality affect Default Risk? The Role of Growth Opportunities and Stock Liquidity. International Review of Economics and Finance 58: 422-48. [CrossRef]

Amel-Zadeh, Amir, and George Serafeim. 2018. Why and How Investors Use ESG Information: Evidence from a Global Survey. Financial Analysts Journal 74: 87-103. [CrossRef]

Arellano, Manuel, and Olympia Bover. 1995. Another Look at the Instrumental Variable Estimation of Error-Eomponents Models. Journal of Econometrics 68: 29-51. [CrossRef]

Ashbaugh-Skaife, Hollis, Daniel W. Collins, and Ryan LaFond. 2006. The Effects of Corporate Governance on Firms' Credit Ratings. Journal of Accounting and Economics 42: 203-43. [CrossRef]

Attig, Najah, Sadok El Ghoul, Omrane Guedhami, and Jungwon Suh. 2013. Corporate Social Responsibility and Credit Ratings. Journal of Business Ethics 117: 679-94. [CrossRef]

Barnett, Michael L. 2007. Stakeholder Influence Capacity and the Variability of Financial Returns to Corporate Social Responsibility. Academy of Management Review 32: 794-816. [CrossRef]

Bedendo, Mascia, and Paolo Colla. 2015. Sovereign and Corporate Credit Risk: Evidence from the Eurozone. Journal of Corporate Finance 33: 34-52. [CrossRef]

Bhojraj, Sanjeev, and Partha Sengupta. 2003. Effect of Corporate Governance on Bond Ratings and Yields: The Role of Institutional Investors and Outside Directors. Journal of Business 76: 455-75. [CrossRef]

Blundell, Richard, and Stephen Bond. 1998. Initial conditions and moment restrictions in dynamic panel data models. Journal of Econometrics 87: 115-43. [CrossRef]

Bouslah, Kais, Lawrence Kryzanowski, and Bouchra M'Zali. 2013. The Impact of the Dimensions of Social Performance on Firm Risk. Journal of Banking and Finance 37: 1258-73. [CrossRef]

Brambor, Thomas, William Roberts Clark, and Matt Golder. 2006. Understanding Interaction Models: Improving Empirical Analyses. Political Analysis 14: 63-82. [CrossRef]

Brogaard, Jonathan, Dan Li, and Ying Xia. 2017. Stock liquidity and default risk. Journal of Financial Economics 124: 486-502. [CrossRef]

Campbell, John Y., and Glen B. Taksler. 2003. Equity Volatility and Corporate Bond Yields. Journal of Finance 18: 2321-50. [CrossRef] 
Capasso, Giusy, Gianfranco Gianfrate, and Marco Spinelli. 2020. Climate change and credit risk. Journal of Cleaner Production 266: 121634. [CrossRef]

Capelle-Blancard, Gunther, and Petit. 2015. The Weighting of CSR Dimensions: One Size Does Not Fit All. Business $\mathcal{E}$ Society 56: 919-43.

Chatterji, Aaron K., David I. Levine, and Michael W. Toffel. 2009. How well do social ratings actually measure corporate social responsibility? Journal of Economics and Management Strategy 18: 125-69. [CrossRef]

Chava, Sudheer. 2014. Environmental Externalities and Cost of Capital. Management Science 60: 2111-380. [CrossRef]

Chen, Huafeng Jason, Marcin Kacperczyk, and Hernan Ortiz-Molina. 2012. Do Nonfinancial Stakeholders Affect the Pricing of Risky Debt? Evidence from Unionized Workers. Review of Finance 16: 347-83. [CrossRef]

Coase, Ronald H. 1934. The Nature of the Firm. Economica 4: 386-405. [CrossRef]

Collin-Dufresne, Pierre, Robert S. Goldstein, and J. Spencer Martin. 2001. The Determinants of Credit Spread Changes. The Journal of Finance 56: 2177-207. [CrossRef]

Corò, Filippo, Alfonso Dufour, and Simeone Varotto. 2013. Credit and Liquidity Components of Corporate CDS Spreads. Journal of Banking and Finance 37: 5511-25. [CrossRef]

Das, Sanjiv R., and Paul Hanouna. 2009. Hedging Credit: Equity Lquidity Matters. Journal of Financial Intermediation 18: 112-23. [CrossRef]

Das, Sanjiv R., Paul Hanouna, and Atulya Sarin. 2009. Accounting-Based versus Market-Based Cross-Sectional Models of CDS Spreads. Journal of Banking and Finance 33: 719-30. [CrossRef]

Drago, Danilo, Concetta Carnevale, and Raffaele Gallo. 2019. Do Corporate Social Responsibility Ratings affect Credit Default Swap Spreads? Corporate Social Responsibility and Environmental Management 26: 644-52. [CrossRef]

Duan, Jin Chuan. 1994. Maximum Likelihood Estimation using Price Data of the Derivative Contract. Mathematical Finance 4: 155-67. [CrossRef]

Duan, Jin Chuan, and Elisabeth Van Laere. 2012. A Public Good Approach to Credit Ratings—From Concept to Reality. Journal of Banking and Finance 36: 3239-47. [CrossRef]

Eccles, Robert G., and Judith C. Stroehle. 2018. Exploring Social Origins in the Construction of ESG Measures. Available online: https://ssrn.com/abstract=3212685 (accessed on 1 June 2020).

El Ghoul, Sadok, Omrane Guedhami, and Yongtae Kim. 2017. Country-Level Institutions, Firm Value, and the Role of Corporate Social Responsibility Initiatives. Journal of International Business Studies 48: 360-85. [CrossRef]

Fabozzi, Frank J., Steven V. Mann, and Moorad Choudhry. 2003. Measuring and Controlling Interest Rate and Credit Risk. Hoboken: John Wiley \& Sons, Ltd.

Ge, Wenxia, and Mingzhi Liu. 2015. Corporate Social Responsibility and the Cost of Corporate Bonds. Journal of Accounting and Public Policy 34: 597-624. [CrossRef]

Girerd-Potin, Isabelle, Sonia Jimenez-Garcès, and Pascal Louvet. 2014. Which Dimensions of Social Responsibility Concern Financial Investors? Journal of Business Ethics 121: 559-76. [CrossRef]

Goss, Allen, and Gordon S. Roberts. 2011. The Impact of Corporate Social Responsibility on the Cost of Bank Loans. Journal of Banking and Finance 35: 1794-810. [CrossRef]

Gutierrez-Nieto, Begona, Carlos Serrano-Cinca, and Juan Camon-Cala. 2016. A Credit Score System for Socially Responsible Lending. Journal of Business Ethics 133: 691-701. [CrossRef]

Hoepner, Andreas, Ioannis Oikonomou, Bert Scholtens, and Michael Schröder. 2016. The Effects of Corporate and Country Sustainability Characteristics on The Cost of Debt: An International Investigation. Journal of Business Finance and Accounting 43: 158-90. [CrossRef]

Huang, Jun, Wei Hu, and Guowei Zhu. 2018. The Effect of Corporate Social Responsibility on Cost of Corporate Bond: Evidence from China. Emerging Markets Finance and Trade 54: 255-68. [CrossRef]

Jiraporn, Pornsit, Napatsorn Jiraporn, Adisak Boeprasert, and Kiyoung Chang. 2014. Does Corporate Social Responsibility (CSR) Improve Credit Ratings? Evidence from Geographic Identification. Financial Management 43: 505-31. [CrossRef]

Jung, Juhyun, Kathleen Herbohn, and Peter Clarkson. 2018. Carbon Risk, Carbon Risk Awareness and the Cost of Debt Financing. Journal of Business Ethics 150: 1151-71. [CrossRef]

Kane, Gregory D., Uma Velury, and Bernadette M. Ruf. 2005. Employee Relations and the Likelihood of Occurrence of Corporate Financial Distress. Journal of Business Finance and Accounting 32: 1083-106. [CrossRef] 
Khan, Mozaffar, George Serafeim, and Aaron Yoon. 2016. Corporate Sustainability: First Evidence on Materiality. The Accounting Review 91: 1697-724. [CrossRef]

Kiesel, Florian, and Felix Lücke. 2019. ESG in credit ratings and the impact on financial markets. Financial Markets, Institutions and Instruments 28: 263-90. [CrossRef]

Kim, Moshe, Jordi Surroca, and Josep A. Tribó. 2014. Impact of Ethical Behavior on Syndicated Loan Rates. Journal of Banking and Finance 38: 122-44. [CrossRef]

Klein, Christian, and Cristoph Stellner. 2014. Does sovereign risk matter? New evidence from Eurozone corporate bond ratings and zero-volatility spreads. Review of Financial Economics 23: 64-74. [CrossRef]

Klock, Mark. S., Sattar. A. Mansi, and William F. Maxwell. 2005. Does Corporate Governance Matter to Bondholders? Journal of Financial and Quantitative Analysis 40: 693-719. [CrossRef]

Kölbel, Julian F., Timo Busch, and Leonhardt M. Jansco. 2017. How Media Coverage of Corporate Social Irresponsibility Increases Financial Risk. Strategic Management Journal 38: 2266-84. [CrossRef]

La Rosa, Fabio, Giovanni Liberatore, Francesco Mazzi, and Simeone Terzani. 2018. The impact of corporate social performance on the cost of debt and access to debt financing for listed European non-financial firms. European Management Journal 36: 519-29. [CrossRef]

Lee, Hwang Hee, and Jung-Soon Hyun. 2019. The asymmetric effect of equity volatility on credit default swap spreads. Journal of Banking and Finance 98: 125-36. [CrossRef]

Lee, Jongsub, Andy Naranjo, and Stace Sirmans. 2016. Exodus from Sovereign Risk: Global Asset and Information Networks in the Pricing of Corporate Credit Risk. Journal of Finance 71: 1813-56. [CrossRef]

Longstaff, Francis, Sanjay Mithal, and Eric Neis. 2005. Corporate Yield Spreads: Default Risk or Liquidty? New evidence from the credit default swap market. Journal of Finance 60: 2213-53. [CrossRef]

Magnanelli, Barbara Sveva, and Maria Federica Izzo. 2017. Corporate Social Performance and Cost of debt: The Relationship. Social Responsibility Journal 13: 250-65. [CrossRef]

Mattingly, James E. 2015. Corporate Social Performance: A Review of Empirical Research Examining the Corporation-Society Relationship Using Kinder, Lydenberg, Domini Social Ratings Data. Business and Society 56: 796-839. [CrossRef]

Menz, Klaus Michael. 2010. Corporate Social Responsibility: Is it Rewarded by the Corporate Bond Market? A Critical Note. Journal of Business Ethics 96: 117-34. [CrossRef]

Nandy, Monomita, and Suman Lodh. 2012. Do Banks Value the Eco-Friendliness of Firms in their Corporate Lending Decision? Some Empirical Evidence. International Review of Financial Analysis 25: 83-93. [CrossRef]

Nizam, Esma, Adam Ng, Ginanjar Dewandaru, Ruslan Nagayev, and Malik Abdulrahman Nkoba. 2019. The impact of social and environmental sustainability on financial performance: A global analysis of the banking sector. Journal of Multinational Financial Management 49: 35-53. [CrossRef]

Oikonomou, Ioannis, Chris Brooks, and Stephen Pavelin. 2014. The Effects of Corporate Social Performance on the Cost of Corporate Debt. The Financial Review 49: 49-75. [CrossRef]

Orlitzky, Marc, Frank L. Schmidt, and Sara L. Rynes. 2003. Corporate Social and Financial Performance: A Meta-analysis. Organization Studies 24: 403-41. [CrossRef]

Perrault, Elise, and Michael A. Quinn. 2018. What Have Firms Been Doing? Exploring What KLD Data Report About Firms' Corporate Social Performance in the Period 2000-10. Business and Society 57: 890-928. [CrossRef]

PRI. 2017. Shifting Perceptions: ESG, Credit Risk and Ratings-Part 1: State of Play. Available online: https://www.unpri.org/download_report/36678 (accessed on 1 June 2020).

PRI. 2019. Shifting Perceptions: ESG, Credit Risk and Ratings-Part 3: From Disconnects to Action Areas. Available online: https://www.unpri.org/download?ac=5819 (accessed on 1 June 2020).

Roodman, David. 2009. How to do xtabond2: An Introduction to difference and system GMM in Stata. The Stata Journal 9: 86-136. [CrossRef]

Schaefer, Stephen M., and Ilya A. Strebulaev. 2008. Structural Models of Credit Risk are Useful: Evidence from Hedge Ratios on Corporate Bonds. Journal of Financial Economics 90: 1-19. [CrossRef]

Sharfman, Mark P. 1996. The Construct Validity of the Kinder, Lydenberg \& Domini Social Performance Ratings Data. Journal of Business Ethics 15: 287-96.

Sharfman, Mark P., and Chitru S. Fernando. 2008. Environmental Risk Management and the Cost of Capital. Strategic Management Journal 29: 569-92. [CrossRef]

Stellner, Christoph, Christian Klein, and Bernhard Zwergel. 2015. Corporate Social Responsibility and Eurozone Corporate Bonds: The Moderating Role of Country Sustainability. Journal of Banking E Finance 59: 538-49. 
Su, Weichieh, Mike W. Peng, Weiqiang Tan, and Yan-Leung Cheung. 2016. The Signaling Effect of Corporate Social Responsibility in Emerging Economies. Journal of Business Ethics 134: 479-91. [CrossRef]

Sun, Wenbin, and Kexiu Cui. 2014. Linking Corporate Social Responsibility to Firm Default Risk. European Management Journal 32: 275-87. [CrossRef]

Surroca, Jordi, Josep A. Tribó, and Sandra A. Waddock. 2010. Corporate Responsibility and Financial Performance: The Role of Intangible Resources. Strategic Management Journal 31: 463-90. [CrossRef]

Tang, Dragon Yongjun, and Hong Yan. 2010. Market Conditions, Default Risk and Credit Spreads. Journal of Banking and Finance 34: 724-34. [CrossRef]

Tolikas, Konstantinos, and Nikolas Topaloglou. 2017. Is default risk priced equally fast in the credit default swap and the stock markets? An empirical investigation. Journal of International Financial Markets, Institutions and Money 51: 39-57. [CrossRef]

UN Environment and World Bank. 2017. Roadmap for a Sustainable Financial System. Available online: http: //unepinquiry.org/publication/roadmap-for-asustainable-\%0Afinancial-system/ (accessed on 1 June 2020).

UN. 2019. United Nations Secretary-General's Roadmap for Financing the 2030 Agenda for Sustainable Development 2019-21. Available online: https://www.un.org/sustainabledevelopment/wp-content/uploads/ 2019/07/UN-SG-Roadmap-Financing-the-SDGs-July-2019.pdf (accessed on 1 June 2020).

UNCTAD. 2014. World Investment Report 2014: Investing in the SDGs: An Action Plan. Available online: https://unctad.org/en/PublicationsLibrary/wir2014_en.pdf (accessed on 1 June 2020).

Utz, Sebastian. 2018. Over-investment or risk mitigation? Corporate social responsibility in Asia-Pacific, Europe, Japan, and the United States. Review of Financial Economics 36: 167-93. [CrossRef]

Verwijmeren, Patrick, and Jeroen Derwall. 2010. Employee Well-being, Firm Leverage, and Bankruptcy Risk. Journal of Banking and Finance 34: 956-64. [CrossRef]

Waddock, Sandra A. 2003. Myths and Realities of Social Investing. Organization and Environment 16: 369-80. [CrossRef]

Williamson, Oliver E. 1985. The Economic Institutions of Capitalism. New York: Free Press.

Windmeijer, Frank. 2005. A Finite Sample Correction for the Variance of Linear Efficient Two-Step GMM Estimators. Journal of Econometrics 126: 25-51. [CrossRef]

Xiao, Chengyong, Qian Wang, Taco van der Vaart, and Dirk Pieter van Donk. 2018. When Does Corporate Sustainability Performance Pay off? The Impact of Country-Level Sustainability Performance. Ecological Economics 146: 325-33. [CrossRef]

Zeidan, Rodrigo, Claudio Boechat, and Angela Fleury. 2015. Developing a Sustainability Credit Score System. Journal of Business Ethics 127: 283-96. [CrossRef]

Zerbib, Olivier David. 2019. The Effect of Pro-Environmental Preferences on Bond Prices: Evidence from Green Bonds. Journal of Banking and Finance 98: 39-60. [CrossRef]

Publisher's Note: MDPI stays neutral with regard to jurisdictional claims in published maps and institutional affiliations.

(C) 2020 by the authors. Licensee MDPI, Basel, Switzerland. This article is an open access article distributed under the terms and conditions of the Creative Commons Attribution (CC BY) license (http://creativecommons.org/licenses/by/4.0/). 